\title{
RESPONSABILIDADE CIVIL AUTOMOBILISTICA: ANÁLISE ACERCA DE SEUS ELEMENTOS EXISTENCIAIS
}

\author{
Automobile liablity: analysis about its elements existential
}

\section{Cesar Calo Peghini}

Mestre em Função Social do Direito pela Faculdade Autônoma de Direito - Fadisp. Pósgraduado em Direito Civil e Processo Civil pela Faculdade Escola Paulista de Direito EPD. Professor nos Cursos de Graduação na Faculdade Autônoma de Direito - Fadisp e de Pós-graduação da Escola Paulista de Direito - EPD.

Recebido em: 07.03.2012

Aprovado em: 05.04.2012

\section{ÁreA do Direito: Civil}

Resumo: A responsabilidade civil verifica o dever que certas pessoas têm de reparar o dano causado, tal hipótese se aplica aos acidentes automobilisticos. Referido fato social constitui um problema mundial e nacional. A regulamentação especifica para a presente matéria é insuficiente, pois fixa somente as normas que disciplinam os procedimentos de trânsito, ficando a cargo da legislação civil, estabelecer os ditames da responsabilidade do acidente automotivo, independentemente da responsabilização nas esferas criminal e administrativa. 0 presente, é dividido em duas partes, sendo elas, respectivamente, as caracteristicas gerais da responsabilidade civil automobilistica, bem como em um segundo momento é analisado os elementos ou pressupostos desta responsabilidade, na legislação vigente.

\begin{abstract}
AвSTRACT: The civil liability checks that certain people should have to repair the damage, this hypothesis applies to motor vehicle accidents. Referred to social fact is a global problem and national levels. The specific rules for this matter is insufficient, because only the fixed rules which govern the procedures for transit, leaving it to the civil law, to establish the responsibility of the dictates of the car crash, regardless of accountability in the criminal and administrative spheres. This is divided into two chapters, they are respectively the general characteristics of automobile liability, as well as a second step is analyzing the elements or assumptions of liability to the law.
\end{abstract}


Palavras-chave: Direito civil - Responsabilidade civil - Elementos ou pressupostos da responsabilidade civil automobilística.
KeYwords: Civil law - Civil liability - Elements or assumptions of liability automobile.

SumÁRIO: 1. Introdução - 2. Características gerais da responsabilidade civil: 2.1 Questões preliminares, legislação aplicada, a independência e autonomia entre as instâncias - 3. Elementos ou pressupostos: 3.1 Elementos ou pressupostos da responsabilidade civil: arts. 186 e 927 do CC/2002 - Aplicação quanto aos acidentes automobilísticos: 3.1.1 Ação ou omissão; 3.1.2 Nexo de causalidade; 3.1.3 Culpa; 3.1.4 Dano ou prejuizo - 4. Conclusão - 5. Bibliografia.

"E até hoje, quem se lembra Diz que não foi o caminhão

Nem a curva fatal

Enem a explosão

Johnny era fera demais

Prá vacilar assim

E o que dizem que foi tudo Por causa de um coração partido."

Renato Russo

\section{InTRODUÇãO}

Conceito básico de responsabilidade civil esta vinculado ao dever que incumbe a certas pessoas a reparar o dano causado por ato próprio ou ato de terceiro, ou fato de coisas que dela dependam. Trata-se do estudo da reparação do dano devida a vítima. ${ }^{1}$

O objeto do presente estudo relaciona ao citado instituto, em especial à responsabilidade civil extracontratual, relacionado ao fato social intrínseco da pós-modernidade, conforme demonstremos no decorrer das próximas laudas.

Inicialmente conforme Ipea - Instituto de Pesquisa Aplicada do Governo Federal é possível identificar que os acidentes automobilísticos constituem um problema mundial, pois conforme o Banco Mundial, mais de um milhão de pessoas morreram em acidentes de trânsito em 1999, sendo que $85 \%$ dessas mortes ocorreram em países em desenvolvimento ou subdesenvolvidos. ${ }^{2}$

1. Lisboa, Roberto Senise. Manual de direito civil: obrigações e responsabilidade civil. 5. ed. São Paulo: Saraiva, 2010. vol. II, p. 251.

2. IPEA. Relatório executivo - Impactos sociais e econômicos dos acidentes de trânsito nas aglomerações urbanas brasileiras. Disponível em: [www.ipea.gov.br/sites/000/2/ estudospesq/Portugues.pdf]. Acesso em: 21.11.2011. 
De acordo com o referido relatório, o Brasil é reconhecido como um dos recordistas mundiais de acidentes de trânsito, bem como se estima o custo anual de $\mathrm{R} \$ 5,3$ bilhões, para o conjunto das aglomerações urbanas brasileiras, o que representa cerca de $0,4 \%$ do PIB do país. ${ }^{3}$

Referida previsão, possui como fato gerador muitos elementos, dentre eles os custos associados às pessoas, custos do atendimento pré-hospitalar; custos associados aos gastos previdenciários, custos associados aos veículos e custos associados ao gasto institucional. ${ }^{4}$

Referido estudo aponta ainda que para o Estado, entre os anos 2001 e 2003, houveram perdas anuais da ordem de $\mathrm{R} \$ 5,3$ bilhões em 2001 (preços de abril de 2003). Essa pesquisa estimou, inclusive, os custos médios unitários em R \$ 3,3 mil, para os acidentes de trânsito sem vítimas, $\mathrm{R} \$ 17,5$ mil para os acidentes com feridos, e R $\$ 144,5$ mil para os acidentes com mortes. ${ }^{5}$

Ainda conforme noticiado pelo portal R7: 6

"(...) os acidentes envolvendo motocicletas vira problema de saúde pública em Pernambuco, segundo a Secretaria, o número de mortes provocadas por acidentes com moto aumentaram $26,7 \%$ nas rodovias federais que passam pelo Estado. A situação levou o governo de Pernambuco a tratar o caso como problema de saúde pública, e o DER (Departamento de Estradas de Rodagem) já lançou cartilha para orientar motociclistas, especialmente no interior do Estado, onde a incidência de mortes é dez vezes maior do que na capital."

Complementa ainda o referido portal: ${ }^{7}$

"O aumento no número de acidentes tem reflexo nos atendimentos de hospitais. Entre 1998 e 2009, o registro de casos envolvendo acidentes com moto subiu 200\%. De acordo com dados da Secretaria de Saúde local, 52,1\% das vítimas de acidentes com motos morrem em via pública e $42,2 \%$ em hospitais. Os acidentes com moto também engrossam o número de lesões na coluna ver-

3. Idem.

4. Para uma melhor compreensão dos custos decorrentes apresentados, em especial, suas subcategorias, indicamos a leitura do já referido Relatório executivo do Ipea - Instituto de Pesquisa do Governo Federal.

5. IPEA. Op. cit.

6. R7. Acidente com moto vira problema de saúde pública em Pernambuco. Segundo Secretaria de Saúde, 52,1\% das vítimas envolvidas morrem em via pública. R7 Notícias. Disponível em: [http://noticias.r7.com/saude/noticias/acidente-com-moto-vira-problemade-saude-publica-em-pernambuco-20100111.html]. Acesso em: 29.11.2011.

7. Idem. 
tebral dos hospitais ( $40 \%$ dos casos). Segundo a Secretaria, o tempo médio de internação de cada ferido é de três dias, e o gasto médio do SUS (Sistema Único de Saúde) é de R $\$ 953,85$ por pessoa."

Conforme elementos apresentados pode-se afirmar que as causas de acidente de trânsito decorrem da sua grande maioria decorrente de erros humanos que são responsáveis por mais de $90 \%$ dos acidentes registrados, sendo que suas principais formas de incidência são: velocidade excessiva; dirigir sob efeito de álcool; distância insuficiente em relação ao veículo dianteiro; desrespeito à sinalização; e dirigir sob efeito de drogas. ${ }^{8}$

Não obstante, nos termos da pesquisa realizada pela empresa Opinion Research Corporation Internacional, verifica-se que $76 \%$ dos motoristas confessam ter o mau hábito de se distrair com outras atividades enquanto dirigem. ${ }^{9}$

Nesta pesquisa, foi solicitado a 1.016 pessoas, que indicassem um ou mais tipos de situação que as fizeram sofrer um acidente ou, pelo menos, passar um susto no trânsito, nesta hipótese identificou-se que são vetores para estas incidências: separar briga dos filhos - 26\%; apagar cigarro - 22\%; usar o laptop $-21 \%$; conversar com passageiros $-18 \%$; falar ao celular $-13 \% .{ }^{10}$

Ainda, conforme artigo apresentado junto à Unesp de Bauru: ${ }^{11}$

"O veículo a motor, como qualquer outra máquina, exige que o ser humano esteja qualificado tecnicamente e mentalmente para operá-lo seguramente. (...) Um indivíduo com um carro importado de alto valor pode cometer todo tipo de infração apenas para satisfazer seu ego, ao passo que um indivíduo com carro velho e de baixo valor pode cometer os mesmos tipos de infrações também para satisfazer seu ego. (...) A velocidade fascina o ser humano, a ponto de correr simplesmente pelo prazer de correr, mesmo que não tenha nenhum objetivo a ser atingido."

Sendo assim, conforme historicamente é sabido, o veículo automotivo é utilizado muitas das vezes para satisfazer seu ego, bem como utilizar o mesmo para outras finalidades se não aquela exclusivamente de transporte.

Por fim, aponta o artigo supracitado, que vetores determinantes para imprudências são: impunidade, legislação deficiente, fiscalização corrupta e sem

8. UnESP. Acidente automobilístico. Disponível em: [www.bauru.unesp.br/curso_cipa/ artigos/4_transito.htm]. Acesso em: 29.11.2011.

9. Francioni, José Vieira. Trânsito - Acidente ou incidente? Disponível em: [www.transitodez.com.br/artigoacidenteouincidente.html]. Acesso em: 29.11.2011.

10. Idem.

11. Idem. 
caráter educativo, baixo nível cultural e social; baixa valorização da vida; ausência de espírito comunitário e exacerbação do caráter individualista e o uso do veículo como demonstração de poder e virilidade. ${ }^{12}$

Referidos dados, em especial os fatores sociológicos e de fiscalização, ou ainda os reflexos sancionatórios criminais, não serão objeto de analise no referido trabalho, tendo em vista o corte metodológico ora proposto, quando a responsabilidade civil extracontratual, porém não refutar que eles são de importância para uma diminuição progressiva dos acidentes automobilísticos.

Diante de todo acima exposto, o presente trabalho busca analisar a responsabilidade civil extracontratual, em especial seus elementos existenciais diante da jurisprudência nacional que amolda o referido instituto.

\section{Características gerais da ReSponsabilidade CIVIL}

2.1 Questões preliminares, legislação aplicada, a independência e autonomia entre as instâncias

Referidos números e dados apresentados, decorrente de fatos sociais, envolvem diretamente a vida humana, cabendo à legislação, à doutrina e aos tribunais a tarefa de desenvolver e fixar parâmetros para solução destes conflitos.

Conforme é notório, a regulamentação específica para a presente matéria é Código de Trânsito Brasileiro - CTB (Lei 9.503/1997) fixando as normas que disciplinam os procedimentos de trânsito, tais como limites de velocidade, habilitação para dirigir etc., porém não regulamenta a questão atinente à responsabilidade civil.

Em decorrência disto, cabe à legislação civil, em especial nas suas cláusulas gerais previstas nos arts. 186 e 927 do CC/2002, estabelecer os ditames da responsabilidade do acidente automotivo, ressalvadas as hipóteses especiais. ${ }^{13}$

Os elementos de incidência serão analisados posteriormente, pois importante, inicialmente frisar, que uma conduta pode ser classificada ao mesmo tempo como ilícito penal, civil e administrativo.

Nesse caso poderá ocorrer a condenação em todas as esferas ou não, ou seja, na ação civil poderá ser condenado e na ação penal absolvido, pois vale a regra da independência e autonomia entre as instâncias.

12. Idem.

13. Bernardo, Wesley de Oliveira Louzada. Responsabilidade civil automobilística: por um sistema fundado na proteção à pessoa. São Paulo: Atlas, 2009. p. 10. 
Referente a esta independência Flávio Tartuce pontua que: ${ }^{14}$

"Na verdade, tanto o dispositivo civil quanto o enunciado doutrinário acabam consagrando a independência relativa entre os juízos cível e criminal. Em regra, a responsabilidade civil independe da criminal, pelo simples fato de que os elementos do ilícito civil são diferentes dos elementos do ilícito penal. Entretanto, quanto à existência do fato ou sobre a sua autoria, não caberá mais a discussão no civil, se houver decisão no âmbito criminal quanto a estes elementos."

Sendo assim, haverá vinculação entre as instâncias, o que significa que não poderá haver condenação na esfera civil ou administrativa quando for absolvido na esfera penal por inexistência de fato e negativa de autoria.

Esta é a inteligência que trata o regulamento quanto a condenações em âmbito administrativo, que dispõe:

Art. 125 da Lei 8.112/1990: "As sanções civis, penais e administrativas poderão cumular-se, sendo independentes entre si"; bem como o art. 126: "A responsabilidade administrativa do servidor será afastada no caso de absolvição criminal que negue a existência do fato ou sua autoria."

Já no âmbito do direito material cível, dispõe o art. 935 do CC/2002:

"A responsabilidade civil é independente da criminal, não se podendo questionar mais sobre a existência do fato, ou sobre quem seja o seu autor, quando estas questões se acharem decididas no juízo criminal."

Mais específico que os artigos supracitados, o Código de Processo Penal regula a matéria em seus arts. 66 e 67, I. II e III, que dispõe:

"Art. 66. Não obstante a sentença absolutória no juízo criminal, a ação civil poderá ser proposta quando não tiver sido, categoricamente, reconhecida a inexistência material do fato. Art. 67. Não impedirão igualmente a propositura da ação civil:

I - o despacho de arquivamento do inquérito ou das peças de informação;

II - a decisão que julgar extinta a punibilidade;

III - a sentença absolutória que decidir que o fato imputado não constitui crime."

Note-se que, a absolvição no processo penal por inexistência de fato ou negativa de autoria não se confunde com a condenação por insuficiência de provas.

14. Tartuce, Flávio. Direito civil: obrigações e responsabilidade civil. 5. ed. São Paulo: Método, 2010. p. 572. 
E ainda, se o tipo penal exigir dolo na conduta e ela tiver sido praticada com culpa, poderá, haver condenação no âmbito civil, tendo em vista que neste é admitida a culpa levíssima. ${ }^{15}$

Ressalte-se que não há necessidade de suspensão do processo civil ou administrativo para aguardar o julgamento no processo penal. Salvo, se o juiz entender que a suspensão é conveniente a fim de evitar conflito ou divergência de sentenças. ${ }^{16}$

Porém, se houver conflito ou divergência de sentenças, ou seja, se no processo penal for absolvido por negativa de autoria ou inexistência de fato e no concomitante processo civil ou administrativo for ao final condenado, será viável a propositura de ação rescisória. ${ }^{17}$

Com relação às excludentes de ilicitude, dispõe o Código de Processo Penal:

15. "Recurso especial. Civil. Responsabilidade civil. Acidente de trânsito. Absolvição. Juízo criminal. Art. 386, VI, do CPP: ausência de prova suficiente para a condenação. Independência das instâncias penal, cível e administrativa. Pensionamento. Filho menor. Cabimento. Recurso conhecido em parte e, na extensão, provido parcialmente. 1. Dada a independência das instâncias penal, cível e administrativa, o comando inserto no art. 1.525 do CC/1916, correspondente ao art. 925 do atual, obsta a discussão sobre a existência do fato e autoria, quando decididas no juízo criminal; diversamente, a improcedência por ausência de prova suficiente para a condenação não elide a responsabilidade civil. 2. Proclama a jurisprudência desta Corte que, nos casos de morte de filho menor, o pensionamento deve ser de 2/3 do salário mínimo até a época em que a vítima completaria 25 anos quando, ao que se presume, constituiria nova família e diminuiria, assim, o auxílio prestado; a partir de então, o pensionamento é devido à base de 1/3 do salário mínimo, estendendo-se até os eventuais 65 anos da vítima, ou até o falecimento dos pais. 3. Recurso conhecido em parte e, na extensão, provido parcialmente." STJ, REsp 236.404/SC, 4. ${ }^{a}$ T., j. 15.05.2007, rel. Min. Hélio Quaglia Barbosa, DJ 17.09.2007.

16. "Agravo interno. Decisão que negou provimento ao recurso. Independência das esferas cível e criminal. Suspensão do processo na esfera cível. Desnecessidade. Em função da independência das esferas cível e criminal, a suspensão do processo civil até o trânsito em julgado do criminal é uma faculdade do juiz. A sentença prolatada na esfera criminal fundada em falta de provas, não justifica a suspensão do processo na esfera cível." TJMG, Processo 1.0024.06.077947-7/002, j. 03.09.2009, rel. Luiz Carlos Gomes da Mata, DJe 28.09.2009.

17. "Ação rescisória. Sentença penal absolutória por ausência de provas. Art. 386, III, do CPP. Documento novo. Precedentes da Corte. 1. Ainda que possível o ajuizamento da ação rescisória com base em sentença penal absolutória proferida posteriormente ao trânsito em julgado da sentença cível, no caso, fundada a absolvição criminal na falta de provas do fato infracional por parte do réu, não há repercussão na condenação imposta na ação de indenização. 2. Recurso especial conhecido e desprovido." STJ, 
"Art. 65. Faz coisa julgada no cível a sentença penal que reconhecer ter sido o ato praticado em estado de necessidade, em legítima defesa, em estrito cumprimento de dever legal ou no exercício regular de direito." ${ }^{18}$

Por fim, outra questão pertinente quanto ao direito penal, é que a eventual concorrência de culpa do motorista do outro veículo envolvido em acidente de trânsito, não afasta a responsabilidade penal do outro, ou seja, não cabe para efeitos penais a compensação de culpa ${ }^{19}$ Diferentemente, tal situação é viável no cível, sendo admitida a compensação. ${ }^{20}$

Ação de reparação de danos em acidente de veículo de via terrestre é processada pelo procedimento sumário nos termos do art. 275, II, $d$, do CPC, que dispõe:

REsp 593.902/MG, 3. ${ }^{\text {a }}$., j. 14.06.2005, rel. Min. Carlos Alberto Menezes Direito, DJ 22.08.2005, p. 261.

18. "Civil. Ação indenizatória por ato ilícito. Morte do filho da autora. Réu absolvido no juízo criminal em razão de excludente de ilicitude. Ato praticado em legítima defesa. Ausência de excesso doloso ou culposo. Coisa julgada para a jurisdição civil. Sentença reformada. Apelos providos para julgar improcedentes os pedidos. 'Os efeitos da absolvição criminal por legítima defesa devem se estender ao âmbito administrativo e civil' (Min. Felix Fischer). A sentença penal transitada em julgado que absolve o réu com fundamento na legítima defesa faz coisa julgada na jurisdição civil, mormente porque o ato praticado sob essa excludente é lícito, nos termos do art. 160, I,

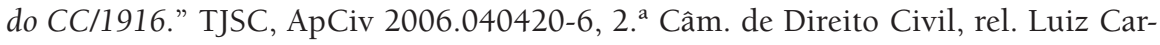
los Freyesleben.

19. "Culpa concorrente. Criminal. Crime de trânsito. Homicídio culposo (art. 302, caput, da Lei 9.503/1997). Colisão de motocicleta com veículo que efetuou manobra de conversão à esquerda, sem as cautelas necessárias. Pretendida a absolvição em face da ausência de culpa, a qual foi atribuída à municipalidade e ao ofendido. elenco probatório firme e convincente acerca da imprudência do apelante, por invasão da via preferencial. Concorrência de culpas que não é albergada pelo direito penal pátrio. Decisão mantida. Recurso não provido. A eventual concorrência de culpa do motorista do outro veículo envolvido em acidente de trânsito não afasta a responsabilidade penal daquele cuja imprudência é estreme de dúvida, além do que, não há, em direito penal, compensação de culpas; logo, o agente responde pelo resultado decorrente de sua conduta imprudente, ainda que a vítima, ou terceiro, por negligência, tenham concorrido para o evento danoso." TJSC, ApCrim 2011.004251-4, 2. ${ }^{a}$ Câm. Crim., j. 12.04.2011, rel. Irineu João da Silva.

20. "Acidente de trânsito. Culpa concorrente. Cível. Acidente de trânsito. Culpa concorrente. Configuração por ausência de cautela de ambos os motoristas dos veículos envolvidos no acidente. Compensação de crédito determinada. Sentença mantida." TJSP, Ap 9091820-40.2006.8.26.0000, 34. ${ }^{a}$ Câm. de Direito Privado, j. 28.03.2011, rel. Cristina Zucchi. 
"Art. 275. Observar-se-á o procedimento sumário:

(...)

II - nas causas, qualquer que seja o valor:

(...)

d) de ressarcimento por danos causados em acidente de veículo de via terrestre."

Porém, de acordo com o REsp 62.318/SP, rel. Min. Waldemar Zveiter, é possível sua conversão em procedimento ordinário com fundamento na celeridade processual, sendo possível dispensar a prova oral sem prejuízo às partes, ${ }^{21}$ bem como, verificado os elementos objetivos é possível o processamento desta ação perante aos juizados especiais cíveis, ou seja, as causas cujo valor não exceda a 40 vezes o salário mínimo.

Quanto às modalidades de responsabilidade, podemos identificar duas espécies a contratual arts. 389 a 420 do CC/2002, e a extracontratual (aquiliana) arts. 927 a 924 do CC/2002. A primeira é o descumprimento do prévio vínculo obrigacional existente entre as partes, por exemplo, a venda de um carro com um vício redibitório; bem como, em um segundo momento, aquela que decorre da inobservância do dever de cuidar que gera dano, por exemplo acidente automotivo; esta última que será objeto do presente trabalho. ${ }^{22}$

Conforme foi proposto, a responsabilidade contratual não é objeto do presente trabalho, porém devemos registrar alguns pontos relevantes quanto à jurisprudência dos tribunais.

O primeiro aspecto relevante é o conflito direto entre o Código de Defesa do Consumidor com o Código Civil. Conforme doutrina de vanguarda, aplicação da norma deve ser a mais favorável ao consumidor, ou seja, norma especial não afasta mais simplesmente a norma geral conforme já proposto anteriormente, pois há uma nova forma de interpretação hermenêutica - com base em normas

21. "Processual e civil. Conversão de rito sumaríssimo em ordinário. Inexistência de prejuízo. Cessão de compromisso de venda e compra não registrado. Perdas e danos. Matéria de fato. I - A jurisprudência do STJ acolhe entendimento no sentido de que, inexistindo prejuízo para a parte adversa, admissível e a conversão do rito sumário para o ordinário. II - No compromisso de compra e venda de imóvel, a cessão avençada, comprovado que o compromissário também vendeu o bem a terceiro que o registrou, perde validade, restando ao prejudicado, reparação em perdas e danos. III - Matéria de fato não se reexamina em especial (Súmula 7 do STJ). IV - Recurso não conhecido." STJ, REsp 62.318/SP, 3. ${ }^{a}$ T., j. 05.09.1995, rel. Min. Waldemar Zveiter.

22. Dinız, Maria Helena. Manual de direito civil. São Paulo: Saraiva, 2010. p. 302. 
principiológicas. Referida forma de interpretação hermenêutica é reconhecida pela doutrina conforme a teoria do diálogo das fontes incluída na doutrina brasileira pela Claudia Lima Marques, ${ }^{23}$ já implementada pela jurisprudência. ${ }^{24}$

Em continuidade, quanto ao contrato de transporte, a responsabilidade no caso de defeito na prestação de serviços incide inicialmente a responsabilidade civil objetiva. ${ }^{25}$ Porém o contrato de transporte de simples cortesia ou benévolo, somente haverá responsabilidade de culpa grave ou dolo. ${ }^{26}$

23. Marques, Claudia Lima; Benjamin, Antonio Herman V.; Miragem, Bruno. Código de Defesa do Consumidor. 2. ed. São Paulo: Ed. RT, 2006. p. 30.

24. "Aplicação da lei mais favorável. Diálogo de fontes. Relativização do princípio da especialidade. Responsabilidade civil. Tabagismo. Relação de consumo. Ação indenizatória. Consumidor e civil. Art. 7. ${ }^{\circ}$ do CDC. Aplicação da lei mais favorável. Diálogo de fontes. Relativização do princípio da especialidade. Responsabilidade civil. Tabagismo. Relação de consumo. Ação indenizatória. Prescrição. Prazo. - O mandamento constitucional de proteção do consumidor deve ser cumprido por todo o sistema jurídico, em diálogo de fontes, e não somente por intermédio do CDC. - Assim, e nos termos do art. $7 .^{\circ}$ do CDC, sempre que uma lei garantir algum direito para o consumidor, ela poderá se somar ao microssistema do CDC, incorporando-se na tutela especial e tendo a mesma preferência no trato da relação de consumo. - Diante disso, conclui-se pela inaplicabilidade do prazo prescricional do art. 27 do CDC à hipótese dos autos, devendo incidir a prescrição vintenária do art. 177 do CC/1916, por ser mais favorável ao consumidor. Recente decisão da 2. ${ }^{a}$ Seção, porém, pacificou o entendimento quanto à incidência na espécie do prazo prescricional de cinco anos previsto no art. 27 do CDC, que deve prevalecer, com a ressalva do entendimento pessoal da Relatora. Recursos especiais providos." STJ, REsp 1.009.591/RS, 3. ${ }^{a}$ T., j. 13.04.2010, rel. Min. Nancy Andrighi.

25. "Processo civil, civil e consumidor. Transporte rodoviário de pessoas. Acidente de trânsito. Defeito na prestação do serviço. Prescrição. Prazo. Art. 27 do CDC. Nova interpretação, válida a partir da vigência do novo Código Civil. (...). Com o advento do Código Civil de 2002, não há mais espaço para discussão. O art. 734 fixa expressamente a responsabilidade objetiva do transportador pelos danos causados às pessoas por ele transportadas, o que engloba o dever de garantir a segurança do passageiro, de modo que ocorrências que afetem o bem-estar do viajante devem ser classificadas de defeito na prestação do serviço de transporte de pessoas. Como decorrência lógica, os contratos de transporte de pessoas ficam sujeitos ao prazo prescricional específico do art. 27 do CDC. Deixa de incidir, por ser genérico, o prazo prescricional do Código Civil. Recurso especial não conhecido." REsp 958.833/RS, 3. ${ }^{a}$ T., j. 08.02.2008, rel. Min. Nancy Andrighi.

26. "Responsabilidade civil. Acidente de trânsito. Transporte de simples cortesia ou benévolo em carroceria aberta, sem proteção. Culpa grave (modalidade culpa consciente) configurada. Valor da condenação. Redução. Impossibilidade. Incidência da Súmula 284 do STF. 1. Em se tratando de transporte desinteressado, de simples cortesia, só haverá possibilidade de condenação do transportador se comprovada a existência 
Prosseguindo, em relação à gasolina adulterada bastante comum nas grandes metrópoles, também se verifica a responsabilidade civil e o dever de indenização, ${ }^{27}$ sendo que neste caso a prova deve ser bem instruída, contando com a apresentação de nota fiscal de consumo, nota fiscal do conserto e denúncia junto a ANP. ${ }^{28}$

Não obstante a responsabilização do autor do dano decorrente desta ação, cumpre registrar que, cumula-se com os crimes identificados pela legislação pátria como os crimes tipificados no art. 288, caput, do CP (formação de quadrilha ou bando); art. 1. ${ }^{\circ}$, I, da Lei 8.176/1991 (crime contra a ordem econômica), art. $7^{\circ}$, III, c/c art. 12, I, da Lei 8.137/1990 (crimes contra a ordem tributária e contra as relações de consumo), e arts. 56 e 60, da Lei 9.605/1998 (crimes ambientais); todos c/c arts. 69 e 29 do CP (concurso material de delitos/concurso de agentes), crimes estes cometidos em organização criminosa, conforme a Lei 9.034/1995.

de dolo ou culpa grave (Súmula 145 do STJ). 2. Resta configurada a culpa grave do condutor de veículo que transporta gratuitamente passageiro, de forma irregular, ou seja, em carroceria aberta, uma vez que previsível a ocorrência de graves danos, ainda que haja a crença de que eles não irão acontecer. 3. Não é possível o conhecimento da pretensão de redução da condenação, pois o recorrente não apontou qualquer lei que teria sido vulnerada pelo acórdão recorrido. Aplica-se, por analogia, na espécie, o disposto na Súmula 284 do STF: É inadmissível o recurso extraordinário, quando a deficiência na sua fundamentação não permitir a exata compreensão da controvérsia. 4. Recurso especial desprovido." STJ, REsp 685.791/MG, 3. ${ }^{a}$ T., j. 18.02.2010, rel. Min. Vasco Della Giustina (Desembargador convocado do TJRS).

27. "Processo civil. Reparação por danos materiais. 1. Provado que a pane mecânica sofrida pelo veículo deu-se em razão do vício na qualidade do óleo diesel com o qual foi abastecido, deve o comerciante do combustível indenizar os danos materiais provocados no mesmo (CDC 18). 2. Negou-se provimento ao agravo retido e ao apelo do réu." TJDF, ApCiv 710308220078070001/DF, 2. T., j. 26.03.2008, rel. Sérgio Rocha.

28. "Gasolina adulterada. Aplicação do Código de Defesa do Consumidor. Nota fiscal. Denúncia ANP. Pedido de reparação de danos. Materiais e morais. Gasolina adulterada. Aplicação do Código de Defesa do Consumidor. Inversão do ônus da prova. Prova pelo autor do dano e do nexo causal. Não comprovação, pela recorrente, da inexistência do defeito no produto. Dever de indenizar os danos ocorridos no veículo. Dano moral, todavia, não caracterizado. Sentença mantida. Recursos improvidos. Há verossimilhança nas alegações do autor, que juntou nota fiscal, datada do dia 14.01.2007, comprovando que abasteceu o carro no posto demandado, promovendo, em 18.01.2008, denúncia junto a ANP que, todavia, não tomou qualquer providência." TJRS, Recurso Inominado 71001550961, 2. ${ }^{a}$ T., j. 16.07.2008, rel. Dra. Vivian Cristina Angonese Spengler. 
Por fim, uma das questões mais controvertidas está relacionada ao tratamento dispare quanto a reparação por danos materiais em rodovia. Tal apontamento tem como fundamento que quando tratar de ação de reparação por danos materiais em rodovia, decorrente de concessão pública, a responsabilidade civil é objetiva. ${ }^{29}$ Porém nos casos de rodovia pública, a responsabilidade civil será subjetiva, tendo em vista a omissão do Estado. ${ }^{30}$

Retomando o objeto de nosso trabalho, a doutrina pátria adota a teoria dualista que entende ser a responsabilidade civil dividida em contratual e a extracontratual, ${ }^{31}$ esta última também chamada de aquiliana em homenagem ao tribuno da plebe Aquilio que no século III a.C. aprovou em plebiscito a Lex Aquilia de Dano. ${ }^{32}$

Cumpre salientar, que esta disposição rompia, naquele momento, com a tipicidade nas hipóteses de indenização, que eram poucas, quais sejam as tipificadas pelo direito civil. Tal hipótese decorre de um ato ilícito sem que haja prévio vínculo contratual entre as partes. ${ }^{33}$

Conforme bem aponta a doutrina, não obstante a responsabilidade cível estar em constante transformação, ${ }^{34}$ deve esta ser analisada de acordo com seus grupos de elementos que cumulados, identificam o reconhecimento do dever

29. "Ação de reparação por danos materiais, decorrentes de acidente automobilístico em rodovia. Atropelamento de animal (cavalo) na pista. Nexo de causalidade. Orçamentos compatíveis com os danos sofridos. Indenização determinada. Responsabilidade objetiva da concessionária, por prestação de serviço público, ex vi do art. $37, \S 6 .^{\circ}$, da CF/1988. Recurso improvido." TJSP, Ap 0015155-98.2007.8.26.0066, 6. ${ }^{a}$ Câm. de Direito Público, j. 07.02.2011, rel. Carlos Eduardo Pachi.

30. "Responsabilidade civil. Indenização por danos morais e estéticos. Autor vítima de grave acidente automobilístico ao colidir com animal em rodovia administrada pelo Dersa. Responsabilidade subjetiva caracterizada pela falta de serviço - recolher o animal da pista e manter sinalização adequada ao longo da via. Lesões graves que impediram o autor de trabalhar. Danos morais, nos quais 'se inserem os danos estéticos, existentes'. Indenização bem fixada. Sentença de procedência. Recurso do réu desprovido." TJSP, Ap 0077454-47.2009.8.26.0000, 13. a Câm. de Direito Público, j. 17.11.2010, rel. Luciana Bresciani.

31. Lisboa, Roberto Senise. Op. cit., p. 274.

32. Venosa, Silvio de Salvo. Direito civil: responsabilidade civil. 6. ed. São Paulo: Atlas, 2006. p. 15.

33. Idem, p. 16.

34. Neste sentido indicamos a leitura de duas grandes teses, a primeira de: Hironaka, Giselda Maria Fernandes Novaes. Responsabilidade pressuposta. 6. ed. São Paulo: Del Rey, 2002; bem como a segunda: TARTUCE, Flávio. Responsabilidade objetiva e risco. 
de reparar um dano patrimonial ou extrapatrimonial, quais sejam: elementos subjetivos: agente e vítima; bem como os elementos objetivos: conduta, dano e nexo de causalidade, ${ }^{35}$ que serão analisados no próximo capítulo evidenciando seus pontos relevantes quanto aos acidentes automobilísticos.

\section{ElEMENTOS OU PRESSUPOSTOS}

\subsection{Elementos ou pressupostos da responsabilidade civil: arts. 186 e 927 do CC/2002 - Aplicação quanto aos acidentes automobilísticos}

Os elementos ou pressupostos estão descritos no art. 186 do CC/2002, que dispõe que: "Aquele que, por ação ou omissão voluntária, negligência ou imprudência, violar direito e causar dano a outrem, ainda que exclusivamente moral, comete ato ilícito".

\section{Conforme Aguiar Dias: ${ }^{36}$}

“(...) não pode haver responsabilidade sem a existência de um dado, e é verdadeiro truísmo sustentar esse princípio, porque, o resultado da responsabilidade civil em obrigação de ressarcir, logicamente não pode concretizar-se onde não há dano."

Sendo assim, os elementos da responsabilidade civil são os mesmos já previstos na codificação anterior. ${ }^{37}$ Porém, sua classificação não é tão simples, tendo em vista sua variação quanto aos doutrinadores. ${ }^{38}$ Desta forma, utilizaremos os elementos mais aventados pela doutrina, ${ }^{39}$ tidos como ação ou omissão, nexo de causalidade, a culpa e por fim, o dano, sendo que todos eles, conforme

A teoria do risco concorrente. São Paulo: Método, 2011. Coleção Professor Rubens Limongi França, vol. 10.

35. Lisboa, Roberto Senise. Op. cit., p. 276.

36. Aguiar Dias, José de. Da responsabilidade civil. 10. ed. Rio de Janeiro: Forense, 1995. vol. II, p. 713.

37. Tepedino, Gustavo; Barbosa, Heloisa Helena; Moraes, Maria Celina Bodin de. Código Civil interpretado conforme a Constituição da República: parte geral e obrigações (arts. 1 a 420). 2. ed. Rio de Janeiro: Renovar, 2007. vol. I, p. 337.

38. Neste sentido, Flávio Tartuce em sua obra, arrola algumas das estruturas possíveis quanto aos elementos da responsabilidade civil. Op. cit., p. 354.

39. Neste sentido: Aguiar Dias, José de. Op. cit.; Diniz, Maria Helena. Op. cit.; Gonçalves, Carlos Roberto. Direito civil brasileiro: responsabilidade civil. 6. ed. São Paulo: Saraiva, 2011; Lisboa, Roberto Senise. Op. cit.; Tartuce, Flávio. Op. cit.; Venosa, Silvio de Salvo. Op. cit.; Rodrigues, Silvio. Direito civil: responsabilidade civil. 19. ed. São Paulo: 
já apontado, serão analisados conforme sua aplicação quanto aos acidentes automobilísticos.

\subsubsection{Ação ou omissão}

O causador do dano responde por ação (conduta comissiva) e por omissão, quando, deixar de praticar um ato que deveria fazer (descumprir um dever ou obrigação preexistente), ou seja, via de regra, somente é responsável somente aquela pessoa que comete o ilícito, ficando excluído o de terceiro, salvo expressa previsão legal como o rol art. 932 do CC/2002. ${ }^{40}$

Sendo assim, o pai e a mãe respondem pelos danos causados pelo seu filho menor que estiver em sua autoridade e companhia, bem como o empregador, ou comitente responde pelos atos do empregado, ou preposto que causam dano no exercício de suas funções.

Analisaremos a referida situação, sob dois aspectos, a legitimidade ativa e passiva nos casos de acidente automobilísticos, independentemente de outras denominações implementadas pela doutrina. ${ }^{41}$

Quando a legitimidade ativa, inicialmente poderá propor a ação somente a vítima do acidente automobilístico, porém em um segundo momento os seus parentes também possuem esta legitimidade no caso de morte daquele. Tal hipótese, consagra uma exceção do dano indireto consagrado no art. 948, II, do CC/2002.

Em um segundo momento, quando o acidente somente envolve os danos no veículo, via de regra, apenas o proprietário poderia propor a reparação do bem, porém o possuidor também é legitimado para a propositura a ação em casos específicos, como nos contratos de leasing e compra e venda com reserva de domínio. ${ }^{42}$

Saraiva, 2002; e STOco, Rui. Tratado de responsabilidade civil. 5. ed. São Paulo: Ed. RT, 2001.

40. Tartuce, Flávio. Op. cit., p. 355-356.

41. Nesta hipótese Roberto Senise Lisboa utiliza termo equivalente, os denominando de autor, sendo aquele responsável pela ocorrência do dano e a vítima que sofre o dano. Op. cit., p. 280-282.

42. Neste sentido: "Ementa: Constitucional, civil e processual civil. Apelação cível. Empresa concessionária de serviço público. Acidente de trânsito. Responsabilidade objetiva. Alegação de culpa exclusiva da vítima. Inocorrência. Conjunto probatório carreado nos autos que atestam de maneira incontestável o nexo de causalidade entre a conduta da empresa concessionária, o ato ilícito praticado e o dano sofrido pelo 
Quanto à legitimidade passiva, encontramos dois aspectos relevantes que devem ser observados, o primeiro deles é a dicotomia "condutor e proprietário", bem como em um segundo momento a responsabilidade civil por ato de terceiro previsto no art. 932 do CC/2002 que serão analisadas abaixo conforme segue.

Inicialmente, tendo como objeto à referida dicotomia a responsabilidade quanto ao acidente, será o condutor do veículo automotor, pois se presume que o bem a este pertence, porém se não houver tal correlação ambos serão responsáveis para reparação do dano solidariamente. A jurisprudência não faz muito esforço em fundamentar esta culpa, ${ }^{43}$ pois, ora fundamenta na culpa in vigilando, ora na culpa in eligendo, ou até mesmo na solidariedade de guarda. ${ }^{44}$

Ainda referente a esta solidariedade, importa notar que a transação de um dos devedores solidários não atinge a outra parte que não transacionou. ${ }^{45}$

apelado. Dever de indenizar configurado. Danos materiais. Alegação de ilegitimidade ativa ad causam da vítima para pleitear indenização pelos danos materiais provocados no automóvel por ela conduzido. Comprovação. Veículo objeto de arrendamento mercantil. Propriedade do bem pertencente ao arrendador. Posse legítima com terceiro arrendatário, estranho ao evento danoso. Não constatação de qualquer relação de titularidade do apelado com o bem avariado. Aplicação da teoria da asserção, considerando-se o momento processual. Denegação da pretensão indenizatória no tocante aos danos no veículo. Reforma da sentença apenas neste capitulo. Demais danos materiais. Comprovação. Dever de indenizar caracterizado. Dano moral evidente. Pretensão de minoração do quantum arbitrado. Inadmissão. Percentual fixado dentro dos patamares de razoabilidade e proporcionalidade. Conhecimento e provimento parcial do apelo." TJRN, ApCiv 9.673/RN (2009.009673-0), 1. a Vara Cível da Comarca de Mossoró/RN, rel. Juíza Maria Neíze de A. Fernandes (convocada).

43. Bernardo, Wesley de Oliveira Louzada. Op. cit., p. 15.

44. "Apelação ação de indenização por danos materiais e lucros cessantes. Responsabilidade civil. Responsabilidade solidária entre o motorista culpado e o proprietário do automóvel que causou dano a terceiro em acidente de trânsito. Culpa in eligendo e in vigilando. Culpa do motorista comprovada por documento oficial, com presunção de veracidade não abalada por testemunhas pelo réu arroladas. Sentença mantida.

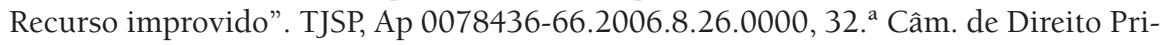
vado, rel. Luis Fernando Nishi.

45. "Responsabilidade civil. Indenização em virtude de morte em colisão de veículos. Devedores solidários. Transação com um dos devedores, por metade, ressalvado o débito da outra metade pelo outro, não extingue a responsabilidade do que não transacionou. Sentença que condena o réu, estranho à transação, ao pagamento de sua parte. Acórdão que exclui a solidariedade do art. 1.518 do Código Civil. Recurso extraordinário conhecido e provido." STF, RE 113.786/RJ, 1. ${ }^{a}$ T., j. 08.09.1987, rel. Oscar Correa. 
Por fim, nos casos de roubo de veículo, inicialmente, conforme Wesley de Oliveira Bernardo ao citar José Aguiar Dias, ${ }^{46}$ afirma que o proprietário responderá solidariamente com o ladrão com quem utilize seu veículo ainda que à sua revelia, pois a guarda jurídica não se confunde com a guarda material.

Não obstante, conforme jurisprudência majoritária, ${ }^{47}$ não há que se falar em direito de reparação do dano quanto ao proprietário.

Em um segundo momento, bem como colocando termo final no presente elemento, a responsabilidade civil por ato de terceiro previsto no art. 932 do CC/2002, quanto a esta situação, temos duas hipóteses de ocorrência à primeira delas decorre da relação jurídica contratual (comodatário, locatário, adquirente com reserva de domínio e oficinas mecânicas), que trataremos em momento oportuno, bem como os casos de pessoas previstas nos incs. I e II do referido artigo. ${ }^{48}$

Sendo assim, são responsáveis os pais, pelos filhos menores que estiverem sob sua autoridade e em sua companhia, ${ }^{49}$ bem como os tutores e os curadores, pelos pupilos e curatelados, que se acharem nas mesmas condições. A responsabilidade nestes casos é objetiva, ${ }^{50}$ e não se discute culpa na escolha (in eligendo) ou na vigilância (in vigilando), pois se aplica a teoria do risco no exercício do poder familiar. ${ }^{51}$ Assim, não se discute culpa.

Questão polêmica, trata da responsabilidade dos pais quanto aos danos causados por seus filhos menores que estiverem sob sua autoridade e companhia. No caso em que os pais separados de direito ou divorciados, como ficaria esta responsabilidade?

46. Bernardo, Wesley de Oliveira Louzada. Op. cit., p. 10.

47. "Acidente automobilístico. Colisão com veículo segurado no momento em que este se achava em poder de meliante que o roubara momentos antes e fugia da polícia. Ajuizamento da ação diretamente contra a seguradora do veículo causador do acidente. Possibilidade. Reconhecimento. Precedentes do STJ. Alegação de ilegitimidade passiva ad causam afastada com acerto. Caso em que, todavia, não é possível o reconhecimento do dever de reparação, dada a inexistência de responsabilidade do segurado, desapossado mediante violência do veículo segurado. Força maior reconhecida na espécie. Disposição contratual dispondo sobre a ausência de cobertura nessa situação. Indenização indevida. Ação improcedente. Recurso provido para esse fim.” TJSP, Ap 992080548430/SP, 33. ${ }^{a}$ Câm. de Direito Privado, j. 25.10.2010, rel. Sá Duarte.

48. Bernardo, Wesley de Oliveira Louzada. Op. cit., p. 17.

49. Peluso, Cezar et al. Código Civil comentado: doutrina e jurisprudência. São Paulo: Manole, 2007. p. 123.

50. Gonçalves, Carlos Roberto. Op. cit., p. 111.

51. Tartuce, Flávio. Op. cit., p. 512-513. 
Inicialmente cumpre ressaltar, que a separação e o divórcio não retiram a autoridade parental, pois os genitores permanecem com o poder familiar. Contudo, pode haver uma alteração na questão da companhia. ${ }^{52}$

Surgem duas correntes sobre o tema, ${ }^{53}$ a primeira delas em que a responsabilidade é apenas do genitor que tiver a companhia jurídica do incapaz quando este causar o dano. Assim, se o dano for causado no dia da guarda materna, só a mãe responde. Se for no dia da visita paterna, só ele responde, ou seja, ninguém pode ser compelido ao impossível ad impossibilia nemo tenetur. Já a segunda corrente aponta que pais e mães sempre respondem solidariamente, pois se o filho causa um dano, houve falha na educação, e, por esta, ambos são responsáveis, tendo em vista a teoria da culpa in educando.

Por fim, tratando-se de guarda compartilhada, não se fala em guarda ou visita e, sendo assim, neste sistema a responsabilidade por atos de filhos menores é de ambos os pais.

\subsubsection{Nexo de causalidade}

O nexo de causalidade é o elemento imaterial da responsabilidade civil, ou seja, a relação de causa e efeito entre a conduta do agente (responsabilidade subjetiva), ${ }^{54}$ o risco da atividade (responsabilidade objetiva) e o dano sofrido pela vítima. Sendo assim, trata-se de um elemento indispensável para a caracterização do dever de indenizar, seja a responsabilidade subjetiva ou objetiva, porém não sendo simples estabelecer no caso concreto sua relação de causa e efeito. ${ }^{55}$

Em decorrência desta dificuldade, a doutrina se divide em três correntes quanto ao nexo de causalidade, quais sejam: (a) teoria do equivalente dos antecedentes ou conditio sine qua non (Von Buri); (b) teoria da causalidade adequada (Von Kries); e (c) teoria dos danos diretos e imediatos conforme segue. ${ }^{56}$

\subsubsection{Teorias do nexo causal}

A teoria do equivalente dos antecedentes ou conditio sine qua non considera que como a causa, toda a circunstância se eliminada mentalmente, faria desa-

52. Gagliano, Pablo Stolze; Pamplona Filho, Rodolfo. Novo curso de direito civil: direito de família. São Paulo: Saraiva, 2011. p. 590.

53. Tartuce, Flávio. Op. cit., p. 512-513.

54. Tepedino, Gustavo; Barbosa, Heloisa Helena; Moraes, Maria Celina Bodin de. Op. cit., p. 343.

55. Venosa, Silvio de Salvo. Op. cit., p. 42.

56. Tartuce, Flávio. Op. cit., p. 367-368. 
parecer o dano,${ }^{57}$ tendo como exemplo hipotético, uma pessoa que foi atropela levemente e sofre simples escoriações. Neste caso, não obstante a gravidade do acidente, esta pessoa necessita de tratamento médico hospitalar, ao ser transportada por uma ambulância, sofre novo acidente independente do anterior e por uma fatalidade vem a falecer.

Neste exemplo, se não houvesse atropelamento, não haveria morte, e, portanto, quem atropelou responde pela morte. Referida teoria não tem aplicação, pois, se levada ao extremo, qualquer responsável indireto pagaria a indenização.

Em continuidade, verifica-se a teoria da causalidade adequada (Von Kries): é considerada causa, toda circunstância apropriada ou idônea para causar a prática ou o dano. Trata-se de uma abstração. No mesmo exemplo da ambulância, o leve atropelamento é adequado para causar fratura no pé, mas não a morte do sujeito ${ }^{58}$ bem como referida teoria é a adotada pelo Código Penal brasileiro (art. 13 do CP)..$^{59}$

Por fim, pontua-se a teoria dos danos diretos e imediatos, referida teoria tem como base a interrupção do nexo causal, sendo que o agente somente responderá pelo dano se entre a sua conduta e o prejuízo não houver a incidência de ato de terceiro, fato jurídico ou a culpa exclusiva da vítima. ${ }^{60}$

Exemplo esclarecedor: um engenheiro projeta equivocadamente uma pista rodoviária, referido erro faz com que o carro colida com o acostamento, destruindo parte deste, bem como populares furtam partes deste automóvel. $\mathrm{O}$ engenheiro não responde pelo o furto, pois este é ato de terceiro, que interrompe o nexo.

Conforme bem aponta a doutrina, uma das maiores dificuldades para o direito é definir qual destas teorias aplicar, tal justificativa tem como fundamento as inúmeras causas que contribuem para o evento danoso. ${ }^{61}$ Porém, conforme cita Flávio Tartuce para Aguiar Dias e Caio Mário, a teoria adotada é a da causalidade adequada, aventada no AgRg no Ag 682.599/RS, porém para Orlando Gomes, Agostinho Alvim e Flavio Monteiro de Barros é a teoria dos danos diretos e imediatos, em razão da redação do art. 403 do CC/2002, bem como do REsp 1.113.804/RS. ${ }^{62}$

57. Idem, ibidem.

58. Lisboa, Roberto Senise. Op. cit., p. 251.

59. Venosa, Silvio de Salvo. Op. cit., p. 42.

60. Gonçalves, Carlos Roberto. Op. cit., p. 315.

61. Tepedino, Gustavo; Barbosa, Heloisa Helena; Moraes, Maria Celina Bodin de. Op. cit., p. 343.

62. Op. cit., p. 367 e ss. 


\subsection{Rompimento do nexo causal e a dispensa do dever de indenizar}

Inicialmente, cumpre ressaltar que o rompimento do nexo causal significa o desaparecimento do dever de indenizar, ou seja, é excludente de responsabilidade civil ${ }^{63}$ já em havendo estado de necessidade ou legítima defesa, não há rompimento de nexo, mas em razão da licitude não há dever de indenizar. ${ }^{64}$

Sendo assim, inicialmente tratar das causa de rompimento do nexo, para somente após tratar do dever da dispensa de indenizar, iniciando pela culpa exclusiva da vítima ou de terceiro, em que Código Civil de 2002 não menciona expressamente culpa exclusiva da vítima como excludente, porque a menção é desnecessária, em razão da eticidade, já que ninguém responde por dano que a vítima causa a si própria. ${ }^{65}$

Continuando, temos a hipótese de incidência do caso fortuito e a força maior, previstos no parágrafo único do art. 393 do CC/2002, que define caso fortuito ou de forca maior de fato necessário, cujos efeitos não eram possíveis evitar ou impedir. Para a lei brasileira os institutos se caracterizam pela irreversibilidade, ou seja, os efeitos não podem ser evitados. A imprevisibilidade não é requisito dos institutos.

Para a lei e a doutrina há controvérsia na classificação destes institutos, havendo várias teorias que os diferencia, contudo há uma unanimidade quanto aos efeitos, pois tanto o caso fortuito (casus minor) quanto a força maior (vis

63. Diniz, Maria Helena. Op. cit., p. 302.

64. Tepedino, Gustavo; Barbosa, Heloisa Helena; Moraes, Maria Celina Bodin de. Op. cit., p. 348.

65. "Civil. Responsabilidade civil do Estado. Indenização por acidente de trânsito. Atropelamento de menor. Culpa exclusiva da vítima. Alegado excesso de velocidade incomprovado. Apelo improvido. Decisão unânime. 1. Conforme depoimento de sua genitora, a criança estava em casa de sua avó, a qual se encontrava dormindo, quando o infante abriu o portão e correu para a pista, vindo a ser atropelado, embora o motorista viesse em velocidade reduzida. 2. O conjunto probatório não deixa dúvidas de que o triste infortúnio ocorreu pela culpa exclusiva da vítima. Aliás, não da vítima, mas dos seus pais ou responsáveis, visto que o menor que à época contava apenas dois anos de idade, não possuía, por óbvio, discernimento suficiente para efetuar a travessia de uma rua de intenso tráfego. 3. (...). 4. Comprovada a culpa exclusiva da vítima, não há que se falar em dever de indenizar, mesmo que se trate de responsabilidade objetiva, porquanto esta é afastada diante da excludente da ilicitude. 5. Apelo uniformemente improvido, incólumes os arts. 1.525 do CC/2002 e 37, \& 6..$^{\circ}$ da Magna Carta." TJPE, Ap 00243030919958170001, 8. ${ }^{a}$ Câm. Civ., j. 07.01.2010, rel. Ricardo de Oliveira Paes Barreto. 
maior), extinguem a obrigação sem que haja indenização, sendo assim, não nos prenderemos em todas as teorias distintivas destes institutos. ${ }^{66}$

A doutrina entende que nos casos de derrapagem ${ }^{67}$ e aquaplanegem ${ }^{68} \mathrm{em}$ rodovias, via de regra implicam em culpa, até prova em contrário.

Em continuidade, a dispensa do dever de indenizar, já citado anteriormente, em havendo estado de necessidade ou legítima defesa, não há que se falar em rompimento de nexo, mas sim tendo em vista a licitude anterior não há, dever de indenizar. ${ }^{69}$

Inicialmente quanto à legítima defesa, pode-se conceituá-la como a reação proporcional a uma injusta agressão atual ou iminente, o ofendido utiliza-se moderadamente dos meios colocados à sua disposição. ${ }^{70}$ Porém, se a legítima defesa causar danos a um terceiro que não aquele que praticou a ameaça, se ocorrer uma legítima defesa putativa, ou o autor agir com excesso, há um ato ilícito e permanece o dever de indenizar. ${ }^{71}$

Outra modalidade de dispensa de indenizar refere-se ao exercício regular de um direito, tal situação decorre de um ato que gera dano, porém oriundo de

66. Venosa, Silvio de Salvo. Op. cit., p. 46.

67. "Responsabilidade civil. Acidente automobilístico. Derrapagem. Conceito. Verificação da culpa. II. E a derrapagem, em si, fruto da imprudência ou da imperícia, caracterizando a culpa, salvo prova da força maior ou razão outra que arrebate a responsabilidade. III. Não importando na apreciação do fato, tomado como certo pelas partes, a reapreciação das provas deixando ver questão federal (arts. 159, 1.521, III, e 1.523 do CC/2002), e provado o dissídio, cabe o extraordinário. Recurso conhecido e provido." STF, RE 65.942/DF, 2. ${ }^{a}$ T., j. 18.10.1970, rel. Thompson Flores, DJ 03.11.1970.

68. "Responsabilidade civil. Acidente de veículo. Derrapagem. Culpa. Recurso especial. Reconhecido no acórdão que o acidente do qual resultou a lesão do autor decorreu da derrapagem do veículo, o que significa ter o motorista perdido o seu controle, impõe-se a conclusão de que houve culpa na produção do resultado._Qualificação jurídica dos fatos que pode ser feita no recurso especial. Recurso conhecido e provido em parte." REsp 236.458/RJ, 4. ${ }^{a}$ T., j. 07.12.1999, rel. Min. Ruy Rosado de Aguiar.

69. Tepedino, Gustavo; Barbosa, Heloisa Helena; Moraes, Maria Celina Bodin de. Op. cit., p. 348.

70. Lisboa, Roberto Senise. Op. cit., p. 354.

71. "Responsabilidade civil. Acidente de trânsito. Regressiva. Culpa dos réus. Reconhecimento. Sentença mantida. Apelação não provida. A legítima defesa ou as demais causas previstas no art. 188 do CC/2002, somente excluem a responsabilidade civil do causador do dano se foram sobejamente provadas." TJSP, Ap s/ Rev 958.211-0/0, 32. ${ }^{a}$ Câm. de Direito Privado, j. 24.03.2006. 
resultado natural legítimo, bem como tal situação se contrapõe nitidamente à noção de abuso de direito previsto no art. 187 do CC/2002. ${ }^{72}$

Por fim, quanto aos casos de responsabilidade civil extracontratual, temos o estado de necessidade que decorre da deterioração ou destruição de coisa alheia, a fim de remover perigo iminente. ${ }^{73}$

Referido instituto incide em duas subespécies, sendo eles o estado de necessidade defensivo, causado a quem criou o perigo, e não há dever de indenizar, bem como o estado de necessidade agressivo, que decorre do agente que não causa dano a quem não criou o perigo, porém, neste caso, cabe ação de regresso contra o real causador do dano, conforme art. 930 do CC/2002. ${ }^{74}$

\subsubsection{Culpa}

O conceito como regra geral decorre da inobservância de um dever de cuidado, tendo como elementos caracterizadores a culpa em sentido amplo ou lato senso que inclui a culpa em sentido estrito ou stricto sensu que é a conduta não intencional que causa o dano; e o dolo que é a culpa intencional que causa o dano, desta forma, pode-se afirmar que a intenção do legislador foi em subjetivar à responsabilidade civil, ou seja, para sua configuração, será necessário identificar o elemento culpa via de regra. ${ }^{75}$

Dois aspectos importantes devem ser ressalvados, o primeiro deles é que para o direito civil culpa, refere-se ao sentido amplo, incluindo ainda o dolo. $\mathrm{O}$ segundo ponto relevante é que o dolo previsto na parte geral do Código Civil é vicio do consentimento e permite a anulação do negócio que não se confunde com o dolo ora estudado. ${ }^{76}$

Conforme doutrina balizada, são modalidades de culpa (art. 186 do CC/2002), a imprudência que decorrente da culpa exteriorizada por uma ação,

72. Tepedino, Gustavo; Barbosa, Heloisa Helena; Moraes, Maria Celina Bodin de. Op. cit., p. 349.

73. Lisboa, Roberto Senise. Op. cit., p. 354.

74. "Responsabilidade civil. Acidente de trânsito. Réu que alega ter provocado o acidente quando fugia de pessoas que pretendiam matá-lo. Estado de necessidade ou legítima defesa que não excluem o dever de indenizar. Recurso não acolhido." TJSP,

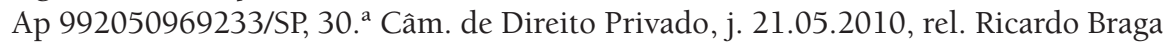
Monte Serrat.

75. Tepedino, Gustavo; Barbosa, Heloisa Helena; Moraes, Maria Celina Bodin de. Op. cit., p. 337.

76. Tartuce, Flávio. Op. cit., p. 357. 
como o exemplo, dirigir acima da velocidade permitida, a negligência que deriva da culpa por omissão, como exemplo, fazer a conversão sem sinalizar. ${ }^{77}$ Por fim, a imperícia, objeto da culpa no exercício de profissão ou ofício, como exemplo, o motorista contratado que dirige em alta velocidade. Desta forma, podemos afirmar que a imperícia não é uma modalidade autônoma e sim a negligência ou a imprudência profissional. ${ }^{78}$

Em regra, conforme já apontado, na responsabilidade subjetiva somente haverá o dever de indenizar em razão da conduta culposa do agente, tal ideia já estava presente no direito romano com a leitura de Ulpiano sobre a Lex Aquilia. ${ }^{79}$

O problema é que o ônus de provar a culpa será sempre da vítima do dano automobilístico, tal situação é tormentosa, pois, muitas vezes, existem apenas testemunhas presenciais, surgindo assim, versões antagônicas narradas pelas partes envolvidas, sendo necessário o julgamento improcedente, ainda que haja vítimas graves ou fatais. ${ }^{80}$

Em razão das dificuldades, o direito percebe a insuficiência da teoria da responsabilidade subjetiva, a doutrina e a jurisprudência têm criando presunções de culpa, as quais possibilita o benefício da inversão do ônus da prova contra o causador do dano.

O primeiro exemplo é a colisão de veículo na traseira de outro, nesta situação, cabe ao motorista que trafega atrás tomar cautelas recomendáveis, pois tem uma visão privilegiada, bem como condições de evitar os acidentes. ${ }^{81}$

77. Diniz, Maria Helena. Op. cit., p. 296.

78. Tartuce, Flávio. Op. cit., p. 358.

79. Venosa, Silvio de Salvo. Op. cit., p. 15.

80. "Apelação cível. Responsabilidade civil em acidente de trânsito. Colisão em via sinalizada. Sinal vermelho. Prova contraditória e insuficiente. Recurso parcialmente provido. Pedido contraposto julgado improcedente. Não se extraindo da prova coligida elementos seguros que apontem quem foi o motorista que ultrapassou o sinal vermelho do semáforo, provocando com isso a colisão, impõe-se a improcedência do pedido contido na demanda." TJMG. ApCiv 3.524/MS (2009.003524-4), 2. ${ }^{a}$ T., j. 06.10.2009, rel. Des. Julizar Barbosa Trindade.

81. "Ação de reparação de danos. Acidente de veículo. Responsabilidade do réu pelo acidente. Colisão na parte traseira do veículo do autor. Culpa presumida. Inversão do ônus probatório. Ausência de provas pelo réu de forma a elidir a presunção de culpa. Decisão mantida. Recurso improvido." TJSP, Ap 0017543-79.2010.8.26.0482, 32. ${ }^{a}$ Câm. de Direito Privado, j. 15.09.2011, rel. Ruy Coppola. 
Outra modalidade de presunção é motorista que trafega na via secundária e adentra a via principal, caso venha a ocorrer um acidente, este possui a culpa presumida, pelo princípio da confiança. ${ }^{82}$

Outra questão que sempre é sustentada nos tribunais, decorre do veículo estacionado em local proibido, esta também é uma presunção do dever de indenizar, conforme se verifica na jurisprudência não é caso de presunção, sendo necessária a analise dos fatos. ${ }^{83}$

Uma última presunção trata-se do motorista desabilitado, pois o Código de Trânsito Brasileiro, estabelece no seu art. 140 e ss., que para dirigir veículos automotores se faz necessário a obtenção da habilitação, bem como no caso do descumprimento, haverá a incidência de infração gravíssima, que compõe, pagamento de multa e apreensão do veículo.

Nesta hipótese, se o motorista desabilitado se envolve em acidente de trânsito, conforme Wilson Melo da Silva e Aguiar Dias, ${ }^{84}$ incorre na culpa "contra a legalidade", ou seja, este seria responsável, salvo se provar caso fortuito ou força maior. Todavia, na atualidade, somente a falta de habilitação não é capaz por si só de evidenciar a necessidade de indenizar. ${ }^{85}$

82. "Acidente de veículo. Reparação de dano. Veículo que adentra na rodovia sem as cautelas necessárias. Colisão. Presunção de culpa. Inversão do ônus probandi. Recurso desprovido. Age com imprudência o condutor de veículo que efetua manobra para adentrar via preferencial, proveniente de retorno em via secundária, interrompendo a preferência de passagem do veículo que provem da direita em via referencial. Exegese dos arts. 29, III, a e 44 do Código de Trânsito Brasileiro. Compete ao condutor que, adentrando na via preferencial sofre colisão com outro veículo que por ela trafegava, o ônus de demonstrar fato modificativo ou desconstitutivo da preferência de passagem. Recurso não provido." TJSP, Ap 0104435-55.2005.8.26.0000, 35. ${ }^{a}$ Câm. de Direito Privado, j. 01.08.2011, rel. Clóvis Castelo.

83. "Civil. Ação de indenização por danos materiais. Acidente de trânsito. Colisão na dianteira de veículo estacionado. Culpa evidente do condutor do veículo abalroador. Irregularidade do estacionamento. concausa, porém não determinante. dever de indenizar caracterizado. Apelo improvido. Sentença mantida. 1. Age com culpa evidente e manifesta o condutor que, de forma negligente e imperita, imprime ao automóvel que dirige velocidade incompatível com a via em que trafega e atinge o veículo que se encontra estacionado, abalroando sua parte dianteira." TJDF, ACJ 0118617 37.2006.807.0001, 2. ${ }^{a}$ T. Recursal dos Juizados Especiais Cíveis e Criminais do DF, j. 16.06.2009, rel. José Guilherme de Souza.

84. Bernardo, Wesley de Oliveira Louzada. Op. cit., p. 13.

85. "Ementa: Ação de indenização. Acidente de trânsito. Culpa demonstrada. Condutor inabilitado. Irrelevância. Danos morais. Quantum indenizatório. A falta de habilitação, 


\subsubsection{Da culpa ao risco: responsabilidade civil objetiva}

Conforme já aventado, a responsabilidade, via de regra, é subjetiva, ou seja, só há o dever de indenizar em razão da conduta culposa do agente. Porém, conforme é sabido, o maior problema nesta modalidade de responsabilização é o ônus de prova, ou seja, a prova da culpa deverá ser apresentada pela vítima do dano, e em razão das dificuldades na sua produção, o próprio sistema se adéqua surgindo às presunções de dano. ${ }^{86}$

Posteriormente, adota-se a noção de responsabilidade objetiva, ou seja, fundada no risco, em que a conduta do agente não é relevante (a culpa é abolida), sendo aplicada a teoria do risco. ${ }^{87}$

A doutrina separa o risco em quatro teorias, sendo elas a do risco integral; a do risco administrativo; a do risco proveito; e a do risco criado, que serão analisadas pontualmente. ${ }^{88}$

A primeira das teorias, ou seja, a do risco integral, também denominada de "risco exacerbado" trata-se de teoria excepcionalíssima, em que o agressor responde pelo dano, mesmo sem existir o nexo causal, basta uma ação e o dano, não cabe matéria de defesa às excludentes de responsabilidade civil, ou seja, ainda que haja caso fortuito, força maior ou culpa exclusiva da vítima, o agente continua obrigado a indenizar. ${ }^{89}$

Importante notar que esta não é a teoria adotada pelo Código de Defesa do Consumidor, pois os arts. 12 e $14, \S 3 .^{\circ}$, do CDC, trazem excludentes da responsabilidade do fornecedor, como exemplo da culpa exclusiva do consumidor ou do terceiro. Porém, no Brasil a teoria é adotada com relação aos danos ambientais (Lei 6.938/1981), bem como para grande parte da doutrina também com relação aos danos nucleares ${ }^{90}$ que tem pouca ou nenhuma interferência com o objeto do presente.

ainda que reveladora de personalidade infensa à prudência e à disciplina legal, não tem qualquer influência no campo da responsabilidade civil, se despicienda para a eclosão do evento danoso e a causa eficiente deste não puder ser atribuída ao condutor inabilitado. Presente a prova da culpa do réu pelo evento danoso, mostra-se presente o dever indenizatório." TJMG, ApCiv 1.0243.06.000432-8/001, j. 26.08.2009, rel. Des. Selma Marques.

86. Bernardo, Wesley de Oliveira Louzada. Op. cit., p. 54-68.

87. Dinız, Maria Helena. Op. cit., p. 297.

88. Tartuce, Flávio. Op. cit., p. 459.

89. Lisboa, Roberto Senise. Op. cit., p. 365.

90. Tartuce, Flávio. Op. cit., p. 459. 
Conforme Carlos Roberto Gonçalves ${ }^{91}$ a teoria do risco administrativo prevista no art. 37, \& 6. ${ }^{\circ}$, da CF/1988 e no art. 43 do CC/2002 são decorrentes de atos das pessoas jurídicas de direito público e as de direito privado prestadoras de serviços públicos que responderão pelos danos que seus agentes causarem a terceiros, assegurado o direito de regresso nas hipóteses de dolo ou culpa.

Sendo assim, nos casos de acidentes decorrentes dos atos de seus agentes, a responsabilidade civil é objetiva. ${ }^{92}$ Porém, deve-se observar se o agente estava na condição de servidor público, pois em caso contrário não há dever de indenizar do Estado. ${ }^{93}$

Cabe ao Estado o direito de assegurado o direito de regresso nas hipóteses de dolo ou culpa. ${ }^{94}$

Em se tratando de ação do Estado, basta a vítima provar a ação, o nexo e o dano para que surja o dever de indenizar. Contudo, em se tratando de omissão, entende-se que a responsabilidade é subjetiva, ou seja, a vítima deve demonstrar culpa do Estado. ${ }^{95}$

91. Gonçalves, Carlos Roberto. Op. cit., p. 152.

92. "Responsabilidade civil do Estado. Ação de reparação de danos materiais. Acidente automobilístico. Veículo oficial conduzido por servidor público, que colidiu em veículo particular. Ausência de comprovação, pela Fazenda do Estado, de culpa exclusiva da vítima. Conjunto probatório que permite concluir pela culpa exclusiva do servidor que conduzia o veículo oficial. Recurso desprovido." TJSP, Ap 91329130.2006.8.26.0000, 8. ${ }^{a}$ Câm. de Direito Público, j. 21.09.2011, rel. Carvalho Viana.

93. "Apelação cível. Responsabilidade civil do Estado do Paraná. Atropelamento causado por policial militar que ensejou vários danos ao autor. Não configuração do dever de indenizar. Elementos probatórios que demonstram que o policial encontrava-se fora do horário de serviço. Agente que não atuou na qualidade de servidor público. Ato da vida civil. Não configuração de ação ou omissão do Estado. Responsabilidade civil objetiva não caracterizada. Recurso desprovido.” TJPR, ApCiv 0708773-4, 3. . Câm. Civ., j. 23.11.2010, rel. Fernando Antonio Prazeres.

94. "Responsabilidade civil do Estado. Ação regressiva em face do causador do dano. Relação jurídica diversa da existente entre a Administração Pública e a vítima do dano. Direito de regresso previsto na Constituição. Responsabilidade de servidor em caso de culpa ou dolo. Condenação pelo mesmo fato em sede criminal. Culpa comprovada. Procedência do pedido. Recurso provido." TJRJ, Ap 2009.001.23153, 2. a Câm. Civ., j. 24.06.2009, rel. Des. Carlos Eduardo Passos.

95. "Rodovia. Dersa. Responsabilidade subjetiva. Responsabilidade civil. Indenização por danos morais e estéticos. Autor vítima de grave acidente automobilístico ao colidir com animal em rodovia administrada pelo Dersa. Responsabilidade subjetiva caracterizada pela falta de serviço-recolher o animal da pista e manter sinalização adequada ao longo da via. Lesões graves que impediram o autor de trabalhar. Danos morais, nos quais 'se inserem os danos estéticos, existentes'. Indenização bem fixada. 
Esta teoria majoritária é de criação de Celso Antônio Bandeira de Mello e é amplamente adotada pelo STJ como nos REsp 721.439/RJ e REsp 549.812/ CE. Contudo, há julgados nos tribunais estaduais em que o Estado responde objetivamente nos casos de omissão. ${ }^{96}$

No mais temos a teoria do risco proveito que tem incidência sobre aquele sujeito que desenvolve uma atividade econômica de risco, ou seja, objetiva lucro em sua atuação. Em tal situação o agente responde objetivamente pelos danos, esta é a teoria adotada predominantemente pelo Código de Defesa do Consumidor.

Porém, há ainda como a teoria do risco criado sendo aquele que desenvolve qualquer atividade de risco, ou seja, independe da intenção de obtenção de lucro, e nesta hipótese, assim como na situação anterior o agente responde objetivamente.

Não obstante o efeito das suas teorias serem idênticos, conforme exposto, pode-se afirmar que teoria do risco criado é mais ampla que a do risco proveito, pois possui uma área mais ampla de aplicação. ${ }^{97}$

Conforme Wesley de Oliveira Louzada Bernardo, ${ }^{98}$ são requisitos para aplicação destas duas últimas duas correntes os elementos: atividade que é conjunto de atos desenvolvidos visando uma mesma finalidade, bem como o advérbio normalmente, que exige repetição da atividade e opõe-se ao advérbio esporadicamente. Sendo assim, em linhas gerais, afirma o referido autor ser possível aplicar nos casos de acidentes fatais a teoria do risco criado, pois esta foi a opção legislativa, bem como é possível identificar a aplicação dos requisitos, ou seja, uma atividade e o advérbio normalmente, tendo em vista a dificuldade o afastamento da responsabilidade civil subjetiva, em detrimento a dificuldade de provas em muitos casos.

\subsubsection{Dano ou prejuizo}

É essencial a existência do dano para surgir o dever de reparar, pois o dano é elemento essencial do ato ilícito, ${ }^{99}$ tanto é assim, que "a indenização mede-se pela extensão do dano", conforme art. 944 do CC/2002.

Sentença de procedência. Recurso do réu desprovido." Ap 992090774549/SP, 13. ${ }^{a}$ Câm. de Direito Público, j. 17.11.2010, rel. Luciana Bresciani.

96. Tartuce, Flávio. Op. cit., p. 471 e ss.

97. Idem, p. 459.

98. Bernardo, Wesley de Oliveira Louzada. Op. cit., p. 99 e ss.

99. Tepedino, Gustavo; Barbosa, Heloisa Helena; Moraes, Maria Celina Bodin de. Op. cit., p. 338. 
Interessante registrar a variação decorrente do valor das indenizações utilizadas, como exemplo, Wesley de Oliveira Louzada Bernardo ${ }^{100}$ em que o quantum debeatur pode variar de um valor ínfimo para um montante milionário.

Ainda neste sentido, verifica-se de quando é uma lesão a um bem jurídico tutelado, que deve ser certo e atual. ${ }^{101}$ Porém, excepcionalmente, há determinadas situações em que não há necessidade de prova, pois este é presumido, como exemplo a cláusula penal; o dano moral presumido - Súmula 388 do STJ, a simples apresentação do cheque "pré-datado" antes da data combinada (data do vencimento), gera dano moral presumido e via de regra o apontamento indevido no cadastro de maus pagadores gera dano moral presumido, contudo a Súmula 385 do STJ, entende que se houver um apontamento devido, não cabe indenização quanto ao apontamento indevido, mas garante o direito de cancelamento.

\subsubsection{Espécies de dano}

Conforme consta na doutrina, algumas são as espécies de dano, dentre elas temos o dano individual, que decorre a verificação inerente de uma lesão a uma pessoa, bem como o dano social que atinge direitos difusos ou coletivos, dentre eles o valor social do trabalho, o meio ambiente, a infância dentre outros. ${ }^{102}$ Em relação ao dano individual seus desdobramentos práticos e suas

100. Primeiro caso: atropelamento com morte de vítima de 35 anos de idade, que deixa esposa, sem filhos e renda mensal como assalariado de mil reais: a) despesas com funeral (salvo comprovação de despesa superior) R $\$ 4.150,00$; b) Pensão (37 x 12 x $1.000,00$ - 1/3 relativos à despesas próprias) $\mathrm{R} \$ 295.999,70$; c) Danos morais (tomado por base 500 salários mínimos) R $272.500,00$; d) Honorários advocatícios (a taxa média de 10\%) R\$57.264,97; Total da condenação R\$ 629.914,67; e Segundo caso: colisão com morte de casal de posicionais liberais, ambos 35 anos de idade, que deixam um único filho de dois anos e possuíam ambos renda mensal de $\mathrm{R} \$ 10.000,00$ cada: a) despesas com funeral (salvo comprovação de despesa superior) $\mathrm{R} \$ 8.300,00$; b) Valor do veículo no qual a vítima trafegava R $\$ 50.000,00$; c) Pensão (16 x 12 x $20.000,00-1 / 3$ relativos às despesas. próprias) $\mathrm{R} \$ 2.559 .999,70$; c) Danos morais (tomado por base 500 salários mínimos) $\mathrm{R} \$ 545.000,00$; d) Honorários advocatícios (a taxa média de 10\%) R \$ 316.329,95; Total da condenação R \$ 3.479.629,65. Cumpre ressaltar que o valor do salário mínimo utilizado no exemplo foi atualizado com a data base 07.12.2011. Bernardo, Wesley de Oliveira Louzada. Op. cit., p. 117.

101. Tepedino, Gustavo; Barbosa, Heloisa Helena; Moraes, Maria Celina Bodin de. Op. cit., p. 338.

102. Dinız, Maria Helena. Op. cit., p. 298. 
subdivisões que serão analisadas e esgotadas pontualmente tendo em vista sua pertinência com a matéria.

Dentre muitas outras classificações doutrinárias, iremos enfrentar o presente, tendo em conta a corrente majoritária, ou seja, pode se aperceber os danos nas modalidades material, moral, estético. ${ }^{103}$

Havendo dano material, há nítida lesão ao patrimônio da vítima, que se divide em dano positivo ou emergente e lucro cessante frustrado conforme doutrina. ${ }^{104}$

Os prejuízos já sofridos pela vítima (danos positivos) são denominados como dano emergente, que conforme Silvio de Salvo Venosa, é o dano de maior facilidade para sua mensuração, pois ao analisar o quantum devido será necessário somente verificar o patrimônio do lesado antes e depois do acidente, sendo a diferença negativa o valor devido. ${ }^{105}$

Nesta situação não cabe muitas controversas, será indenizado o valor devidamente comprovado no bojo dos autos, tais despesas podem ser as mais diversas, desde despesas com funeral, até necessidade de guincho e armazenamento do veículo.

Porém, importante notar que o art. 389 do CC/2002, dispõe que: "Não cumprida a obrigação, responde o devedor por perdas e danos, mais juros e atualização monetária segundo índices oficiais regularmente estabelecidos, e honorários de advogado".

Neste sentido o REsp 1.134.725/MG, rel. Min Nancy Andrighi assevera a que os arts. 389, 395 e 404 do CC/2002, determinam, de forma expressa, que os honorários advocatícios integram os valores devidos a título de reparação por perdas e danos, bem como complementa que estes honorários são os honorários contratuais, pois os sucumbenciais, por constituir crédito autônomo do advogado, não importam decréscimo patrimonial do vencedor da demanda.

Sendo assim, os honorários contratuais advocatícios integram os valores devidos a título de reparação por perdas e danos, porém o valor cobrado pela atuação do advogado não pode ser abusivo, cabendo ao magistrado analisar as

103. Neste sentido, apesar de dissidências pontuais: Aguiar Dias, José de. Op. cit.; Diniz, Maria Helena. Op. cit.; GonçAlves, Carlos Roberto. Op. cit.; LisboA, Roberto Senise. Op. cit.; Peluso, Cezar et al. Op. cit.; Tartuce, Flávio. Op. cit.; Tepedino, Gustavo; Barbosa, Heloisa Helena; Moraes, Maria Celina Bodin de. Op. cit.; e Venosa, Silvio de Salvo. Op. cit.

104. Diniz, Maria Helena. Op. cit., p. 298-299.

105. Venosa, Silvio de Salvo. Op. cit., p. 32. 
peculiaridades de cada caso e, se for preciso, arbitrar outro valor, podendo para isso utilizar como parâmetro a tabela de honorários da OAB.

A única controvérsia paira sobre os custos para conserto do veículo, ser maior que o próprio valor de mercado do mesmo, nesta hipótese, entende a jurisprudência que o valor de conserto somente pode ser mantido nos casos de carros de colecionador ou raros, sendo assim, em outras hipóteses a reparação do dano seria antieconômica. ${ }^{106}$

Em continuidade, o dano decorrente dos lucros cessantes, incide naquilo em que a vítima razoavelmente deixou de lucrar (danos negativos). ${ }^{107}$ Vamos analisar a matéria sob dois prismas, a primeira delas quando da necessidade de outro veículo para o exercício de suas atividades, bem como em um segundo mento, os lucros cessantes por morte ou por invalidez.

Quanto à hipótese de incidência da locação de veículo, conforme doutrina, a sua indenização se faz necessária quando a vítima necessitava do veículo para suas atividades lucrativas. ${ }^{108}$

Não obstante, a dúvida persiste se todas as vítimas terão direito a locação de um veículo, pois, questiona-se se esta regra somente se aplica nos casos em que a vítima utilize o automóvel como fonte de renda o veículo.

São duas posições, a doutrina de Wladimir Valler citado por Wesley de Oliveira Louzada Bernardo ${ }^{109}$ entende não ser possível aplicar esta regra às pes-

106. "Civil. Responsabilidade civil. Acidente de trânsito. Indenização. Conserto mais dispendioso que o preço do carro. Pagamento de valor correspondente ao preço de veículo semelhante, com a idade que tinha aquele acidentado, na data do sinistro. I Ressalvadas situações especiais (peças de coleções etc.), o custo de reconstituição de veículo acidentado não deve ultrapassar seu valor de mercado; II - Se a recuperação do veículo mostra-se economicamente inviável, a indenização deve corresponder ao valor de um carro semelhante, com a idade que tinha o acidentado, na data do sinistro; III - Para se chegar a este valor, apura-se o valor do veículo na data do sinistro e, a partir de então, corrige-se o respectivo montante, ate a data do pagamento; IV - Na indenização por ato ilícito, incidem juros de $1 \%$ ao mês, desde o evento, ate o último pagamento." STJ, REsp 56.708/SP, 1. ${ }^{a}$ T., REsp 1994/0034419-8, rel. Min. Humberto Gomes de Barros, DJ 10.04.1995, p. 9259.

107. Lisboa, Roberto Senise. Op. cit., p. 296.

108. "Administrativo. Acidente de automóvel. Lucros cessantes comprovados. O taxista será ressarcido pelo lucro que deixou de auferir enquanto seu automóvel comprovadamente permanecia em oficina mecânica após acidente de trânsito em que não teve culpa. Apelação provida." TRF-4 Reg., AC 10.946/RS, 2000.71.00.010946-4, 3. a T., j. 07.11.2005, rel. Carlos Eduardo Thompson Flores Lenz, DJ 30.11.2005, p. 733.

109. Op. cit., p. 34. 
soas que não possuem renda com o automóvel, como estudantes ou donas de casa, porém esta primeira posição não vem prevalecendo na jurisprudência, que admite a locação de veículos, ainda que não se verifique a utilização do mesmo para a atividade profissional. ${ }^{110}$

Em continuidade os lucros cessantes por morte ou por invalidez, nos casos em que a vítima tiver 14 anos ou mais, sendo de baixa renda e auxilie financeiramente seus pais, aplica-se a Súmula 491 do STF que fixa o valor da indenização presumindo lucro cessante no valor de $2 / 3$ do salário mínimo até a idade em que a vítima completaria 24-25 anos (idade em que constituiria a sua própria família). ${ }^{111}$ Não obstante este posicionamento inicial, há julgados no STJ que entendem ser devida aos pais como quantum indenizatório o valor de $1 / 3$ do salário mínimo, até a idade em que pais da vítima completariam 65 anos. ${ }^{112}$

Se a vítima tiver dependentes econômicos, no caso de morte, ou se tornar inválida em razão do ato ilícito, sendo ela empregada (Consolidação das Leis do Trabalho), a indenização será composta pelos 2/3 salários; férias acrescidas, horas extras e FGTS. ${ }^{113}$

110. "Despicienda a discussão acerca da prova do veículo ser necessário ao trabalho desenvolvido pelo dono do automóvel avariado, pois é concebido que a liberdade de ir e vir é direito constitucionalmente assegurado, assim como as atividades de lazer e de trabalho. Destarte, não há que se inquirir sobre a necessidade ou não da finalidade

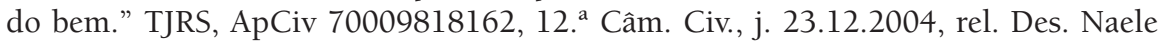
Ochoa Piezza.

111. "Recurso especial. Omissão do acórdão recorrido. Inexistência. Responsabilidade civil. Atropelamento e morte por composição férrea. Vítima. Dona de casa. Indenização por dano material. Cabimento. Pensionamento aos filhos. Limite de idade. Culpa recíproca. Distribuição proporcional dos ônus sucumbenciais. (...) IV - Em casos que tais, o pagamento da pensão será devido aos filhos menores até o limite de 25 anos de idade, quando, presumivelmente, os beneficiários terão concluído sua formação, inclusive em curso universitário, não mais se justificando o vínculo de dependência." STJ, REsp 402.443/MG, 3. ${ }^{a}$ T., rel. Min. Carlos Alberto Menezes Direito.

112. "Civil. Ação de indenização. Atropelamento fatal. Morte de menor, ferimento em outro. Família de baixa renda. Pensionamento devido. Período. Redução do valor para 1/3 após os 25 anos de idade da vítima. Dano moral. Valor. Majoração. I. Em se tratando de família de baixa renda, é devido o pensionamento pela morte de filho menor em acidente causado por veículo da empresa ré, equivalente a $2 / 3$ do salário mínimo dos 14 anos até 25 anos de idade da vítima, reduzido para 1/3 até a data em que o de cujus completaria 65 anos." STJ, REsp 598.327/PR, REsp 2003/0179851-0, 4. ${ }^{a}$ T., j. 16.10.2007, rel. Aldir Passarinho Junior.

113. "Responsabilidade civil. Atropelamento. Morte. Indenização. Danos morais e materiais. Cabimento. Pensionamento. Critérios. Termo ad quem. Sobrevida provável. Sucumbência recíproca. Inocorrência. 2. O Tribunal de origem julgou que 'a pensão 
O cálculo deve ser feito de acordo com a expectativa média de vida do brasileiro, que tradicionalmente é considerada 65 anos, contudo, o IBGE, nos últimos anos, aumentou essa expectativa para 72 anos. Neste sentido existem vários julgados, porém já foi admitido a fixação até 90 anos. ${ }^{114}$

Conforme Carlos Roberto Gonçalves, ${ }^{115}$ ainda que a vítima, ou sua família venha a receber seguro pago por seguradora, ou benefício pago pelo INSS, tais valores não são abatidos da indenização, pois tem causa jurídica distinta, não há o que se falar em enriquecimento sem causa da vítima.

Cumpre ressaltar que não cabe prisão civil pelo inadimplemento dos lucros cessantes, ${ }^{116}$ já em relação ao bem de família este não é garantido, pois o débito decorrente de dívidas alimentares. ${ }^{117}$

devida deve ser o equivalente a dois terços do último salário líquido, incluídas as horas extras, percebido pela vítima'. A decisão recorrida foi lastreada no conjunto probatórios dos autos, oriunda de instrução processual (demonstrativos de pagamento de salário da vítima, relativos aos meses de agosto e setembro de 1994, imediatamente anteriores ao acidente fatal, 14.10.1994, e nos quais constam a indicação de recebimento de 'hora extra a 75\%'). A revisão do acórdão recorrido implicaria em reexame de provas produzidas nas instâncias ordinárias, o que é vedado pela Súmula 7 desta Corte. 3. Consideradas as peculiaridades do caso em questão, vale dizer, atropelamento e morte de trabalhador e pai de família, com 42 anos, deixando companheira e três filhos, o valor fixado pelo Tribunal de origem a título de danos morais mostra-se razoável, limitando-se à compensação do sofrimento advindo do evento danoso. Valor indenizatório mantido na quantia certa de $\mathrm{R} \$ 160.000,00$ (cento e sessenta mil reais), a ser dividido entre os autores recorridos." REsp 698.443/SP, REsp 2004/0150883-2, 4. ${ }^{a}$ T., rel. Min. Jorge Scartezzini, DJ 28.03.2005, p. 288.

114. "Civil. Recurso especial. Atropelamento por trem em via férrea. Vítima fatal. Culpa concorrente. Precedentes. Indenização por danos materiais e morais. Proporcionalidade. Pensão. Serviço doméstico indenizável. Vítima e pensionista com mais de 65 (sessenta e cinco), anos de idade. Termo final. Constituição de capital. Necessidade. Súmula 313 do STJ. Compensação por danos morais. Critérios. Juros moratórios. Súmula 54 do STJ. (...) se o critério do limite dos 65 (sessenta e cinco) anos de idade para o pensionamento fosse aplicado em termos rígidos, ele acabaria por discriminar e prejudicar os idosos, justamente os mais necessitados do pensionamento. Realmente, deixar de pensionar o idoso, porque ele já ultrapassou a idade fixada como limite temporal firmado para tanto pela jurisprudência, seria ferir o princípio da isonomia." STJ, REsp 773.853/RS, REsp 2005/0135201-0, 3. ${ }^{a}$ T., rel. Min. Nancy Andrighi, DJ 22.05.2006, p. 2005.

115. Gonçalves, Carlos Roberto. Op. cit., p. 368-369.

116. Idem, p. 370.

117. "Bem. Família. Exceção. Impenhorabilidade. A Seção rejeitou os embargos por entender que o bem imóvel do devedor não está amparado pela impenhorabilidade pre- 
Ainda, quanto do percebimento das quantias a serem pagas, o art. 475, $q$, do CPC, permite desconto em folha, bem como no caso de invalidez, o art. 950, parágrafo único, do CC/2002, admite a constituição de renda, ou seja, parte dos bens do devedor ficam reservados para que com seus frutos pague a pensão.

Superado o ponto anterior, temos o dano moral que é aquele incidente de um sofrimento (pretium doloris), ou ainda, atinge direitos de personalidade, psíquico, moral e intelectual da vítima, servindo a indenização como um lenitivo, ou seja, amortização da dor ou sofrimento, ou seja, não se trata de ressarcimento, pois a vítima não volta ao estado anterior (statu quo ante). ${ }^{118}$

Referente ao tema, conforme se verifica na doutrina, a questão quanto a reparabilidade do dano moral ou sua possibilidade de cumulação com dano patrimonial ${ }^{119}$ esta superada, porém os embates tem feições quanto ao conceito do próprio instituto, bem como sua liquidação. ${ }^{120}$

Quanto ao conceito do instituto, nos parece mais salutar, o posicionamento que entende ser o dano moral, qualquer sofrimento, turbação ou incômodo que não decorrente de perda patrimonial, pois este conceito é mais ampliativo, e sendo assim, possui maior alcance. ${ }^{121}$

Quanto à liquidação, conforme Maria Helena Diniz, ${ }^{122}$ algumas são as ponderáveis que devemos registrar a seguir:

"Propomos as seguintes regras a serem seguidas pelo órgão judicante no arbitramento para atingir homogeneidade pecuniária na avaliação do dano moral: a) evitar indenização simbólica e enriquecimento sem causa, ilícito ou injusto da vítima; b) não aceitar a tarifação, porque esta requer despersonalização e desumanização, e evitar porcentagem do dano moral; c) diferenciar o

vista na Lei 8.009/1990 quando o crédito for decorrente de alimentos em virtude de acidente de trânsito. As exceções à impenhorabilidade previstas nos arts. $3 .^{\circ}$ e $4 .^{\circ} \mathrm{da}$ referida lei não fazem nenhuma ressalva quanto a se tratar de constrição decorrente ou não de ato ilícito. Precedentes citados: REsp 1.036.376/MG, DJe 23.11.2009; REsp 437.144/RS, DJ 10.11.2003, e REsp 64.342/PR, DJ 09.03.1998.” EREsp 679.456/SP,

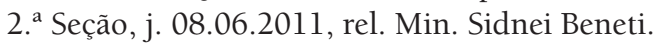

118. Venosa, Silvio de Salvo. Op. cit., p. 35-38.

119. Gonçalves, Carlos Roberto. Op. cit., p. 394.

120. Tepedino, Gustavo; Barbosa, Heloisa Helena; Moraes, Maria Celina Bodin de. Op. cit., p. 339.

121. Idem, p. 340.

122. Dinız, Maria Helena. Op. cit., p. 299-300. 
montante indenizatório segundo a gravidade, a extensão e a natureza da lesão; d) verificar a repercussão pública provocada pelo fato lesivo e as circunstâncias fáticas; e) atentar às peculiaridades do caso e ao caráter antissocial da conduta lesiva; averiguar não só os benefícios obtidos pelo lesante com o ilícito, mas também a sua atitude ulterior e situação econômica; g) apurar o real valor do prejuízo sofrido pela vítima e o lucro cessante, fazendo uso do juízo de probabilidade para averiguar se houve perda de chance ou oportunidade, ou frustração de uma expectativa; h) levar em conta o contexto econômico do país; i) verificar não só o nível cultural e a intensidade do dolo ou grau de culpa (...); j) basear-se em prova firme e convincente do dano; analisar a pessoa do lesado $(\ldots)$; l) procurar harmonização das reparações em casos semelhantes; m) aplicar o critério do justum ante as circunstâncias do caso (...)."

Tanto é assim, que conforme precedentes do STJ, uma vez verificado os pressupostos fáticos, bem como quando se mostrar desarrazoado o valor da indenização, este pode majorar ou diminuir o quantum indenizatório. ${ }^{123}$

Não obstante toda esta sistemática para aplicação do dano mora, conforme atualmente se verifica nos tribunais os casos de morte o valor indenizatório é mensurado em 500 salários mínimos.

"Administrativo. Responsabilidade civil. Indenização. Estado. Juros compostos. Ato ilícito. 1 - Não se conhece de recurso especial quando inexiste

123. "Civil. Indenização. Trânsito. Acidente. Morte. Danos materiais e morais. Pressupostos fáticos. Súmula 7 do STJ. Omissão. Inexistência. Quantum indenizatório. Razoabilidade. Pensão mensal. Redução. (...) 3 - Admite o STJ a redução do quantum indenizatório, quando se mostrar desarrazoado, o que não sucede na espécie, em que houve morte decorrente de acidente de trânsito, dado que as $4 .^{a}$ e $3 .^{a}$ Turmas desta Corte têm fixado a indenização por danos morais no valor equivalente a 500 salários mínimos, conforme vários julgados. (...)" (REsp 713.764/RS, 4. ${ }^{a}$ T., j. 04.03.2008, rel. Min. Fernando Gonçalves); e "Recurso especial. Civil. Dano moral atropelamento. Morte de filho menor. Quantum irrisório. Majoração. Possibilidade. Recurso provido. 1. Incontroverso o pressuposto de culpa exclusiva do recorrido no evento que causou a morte do menor, o quantum indenizatório, fixado na origem em $\mathrm{R} \$ 20.000,00$ (vinte mil reais) mostra-se em descompasso com os parâmetros que vem adotando esta Corte Superior, para casos assemelhados, que vão até 500 salários mínimos. 2. A jurisprudência deste Tribunal é firme no sentido de que o quantum definido pela Corte de origem somente pode ser alterado, em sede de recurso especial, quando manifestamente excessivo ou irrisório, o que, se verifica no caso dos autos; na espécie, o valor da indenização pela perda do filho menor dos recorrentes, deve ser elevado ao montante de $\mathrm{R} \$ 190.000,00$ (cento e noventa mil reais). 3. Recurso especial conhecido e provido parcialmente" (REsp 936.792/SE, 4. ${ }^{a}$ T., j. 04.10.2007, rel. Min. Hélio Quaglia Barbosa). 
prequestionamento no acórdão recorrido da matéria infraconstitucional apontada como violada. (...) 4 - Quantificação da indenização por dano moral. Inexistência, em tal definição, de divergência de tese jurídica. Valor fixado com vinculação a fatos. Impossível ser reapreciado em sede de recurso especial, quando não se afasta do critério da razoabilidade. No caso, o valor fixado foi de 500 (quinhentos) salários mínimos, o que se tem como não exagerado." REsp 139.779/RS, 1. a T., j. 13.11.1997, rel. José Delgado.

Ainda quanto à matéria atinente ao dano moral, conforme doutrina, ${ }^{124}$ tem-se o dano moral indireto, também conhecimento como dano à ricochete, sendo aquele que atinge diretamente uma pessoa ou objeto, mas causa sofrimento ao terceiro (vítima indireta). Tal situação é bastante comum nos casos em que uma pessoa perde um parente em acidente automobilístico.

Um desdobramento natural é identificar a distinção de meros aborrecimentos com os danos morais. Tal ponderação é de suma importância, pois aqueles não configuram dano moral e fazem parte da vida em sociedade.

Este é o entendimento do no Enunciado 159 do CJF que estabelece: "O dano moral, assim compreendido todo o dano extrapatrimonial, não se caracteriza quando há mero aborrecimento inerente a prejuízo material".

O terceiro e último ponto relevante é a não possibilidade da aplicação de dano moral decorrente dos contratos. Tal situação é pacífica na jurisprudência, contudo há precedentes que excepcionam as hipóteses em que as circunstâncias atinentes ao ilícito material têm consequências severas de cunho psicológico, mostrando-se como resultado direto do inadimplemento, a justificar a compensação pecuniária, tal como ocorre na hipótese.

Neste sentido o STJ, AgRg no AgIn 1.010.856/RJ, DJe 01.12.2010; REsp 830.572/RJ, j. 17.05.2011, rel. Min. Luis Felipe Salomão. Reconheceu o dano moral em que há mais de 12 anos houve a assinatura do contrato de promessa de compra e venda de uma unidade habitacional. Contudo, passados mais de 9 anos do prazo previsto para a entrega, o empreendimento imobiliário não foi construído por incúria da incorporadora. Os precedentes citados no julgado foram: REsp 1.072.308/RS, DJe 10.06.2010; REsp 1.025.665/RJ, DJe 09.04.2010; REsp 617.077/RJ, DJe 29.04.2011; AgRg no AgIn 631.106/RJ, DJe 08.10.2008.

Por fim, o dano estético decorre de um dano separado do extrapatrimonial, toda alteração morfológica e irreversível que causa um afeamento da vítima. ${ }^{125}$

124. Lisboa, Roberto Senise. Op. cit., p. 297 e 305.

125. Tartuce, Flávio. Op. cit., p. 418. 
Por muito tempo discutiu-se se era possível cumular a cobrança do dano estético com o dano moral. Tais embates foram supridos pela à Súmula 387 do STJ que dispõe: "É lícita a cumulação das indenizações de dano estético e dano moral". Sendo assim, se a alteração morfológica gerar sofrimento e ainda danos materiais é possível uma tríplice cumulação: dano estético, dano moral, e dano material.

\subsubsection{Impacto dos graus de culpa sobre a indenização}

Inicialmente cumpre salientar que as modalidades da culpa, não afetam o valor da indenização, sendo assim, uma vez verificada a culpa será devida a reparação do dano. ${ }^{126}$ Porém existe, conforme disposição legislativa, graus de culpa, que mitiga a força obrigatória do art. 944 do CC/2002 aplicando a eticidade os eventos danosos. ${ }^{127}$

Dentre os elementos atinentes à culpa, podemos identificar que esta se subdivide em três modalidades, a culpa grave, em que o agente não deseja o resultado e age de maneira tão descuidada que parece desejá-lo, a culpa grave ao dolo se equipara. Neste caso, podemos citar como exemplo a mãe que deixa medicamento sobre a mesa e a criança toma.

Em continuidade temos a culpa leve, esta identificada de acordo com a conduta do homem médio. Mantendo em exemplo anterior, a colocação do medicamento fora do alcance da criança, ou seja, no alto do armário, bem como por fim a culpa levíssima, que o agente adota cautela superior a normal, mas mesmo assim age com culpa. Encerrando as formas exemplificativas, o medicamento que é posto em lugar alto e fora da vista da criança, ou seja, no alto do armário e dentro do armário.

Nas situações em que incidir culpa leve e culpa levíssima haverá o dever de indenizar, porém o quantum devido será reduzido equitativamente, ${ }^{128}$ bem como para que não haja culpa, o armário deve ter todos os requisitos anteriores, porém estar trancado.Sendo assim, em regra, a indenização se mede pela extensão do dano, tal situação encontra-se nitidamente no art. 944 do CC/2002.

Contudo em duas situações específicas o magistrado poderá reduzir a indenização equitativamente em razão dos graus de culpa, A primeira delas refere-

126. Tepedino, Gustavo; Barbosa, Heloisa Helena; Moraes, Maria Celina Bodin de. Op. cit., p. 338.

127. Peluso, Cezar et al. Op. cit., p. 944.

128. Gonçalves, Carlos Roberto. Op. cit., p. 424-425. 
-se excessiva desproporção entre a culpa e o dano, culpa leve ou levíssima ou enorme, conforme parágrafo único do art. 944 do CC/2002.

Isso significa que a vítima suportará parte do prejuízo, o dispositivo representa exceção no sistema, e, portanto, não pode ser aplicado como regra. Equidade significa que o juiz analisa o caso concreto para fixar a indenização, levando em conta o impacto do valor da indenização sobre a pessoa do causador do dano e sua família, sendo assim, o dispositivo permite ao juiz aplicar a ideia de dignidade humana ao agressor. ${ }^{129}$

Referente a esta disposição o Enunciado 46 do CJF intuía que a redução não era possível em todas as hipóteses, pois somente era aplicado na responsabilidade subjetiva, ou seja, onde se discute culpa:

"Art. 944: a possibilidade de redução do montante da indenização em face do grau de culpa do agente, estabelecida no parágrafo único do art. 944 do novo Código Civil, deve ser interpretada restritivamente, por representar uma exceção ao princípio da reparação integral do dano, não se aplicando às hipóteses de responsabilidade objetiva."

Contudo o Enunciado 308 do CJF revogou a parte final do Enunciado 46 do CJF, para permitir esta aplicação. Que se dá na seguinte maneira:

"A possibilidade de redução do montante da indenização em face do grau de culpa do agente, estabelecida no parágrafo único do art. 944 do novo Código Civil, deve ser interpretada restritivamente, por representar uma exceção ao princípio da reparação integral do dano."

129. "Critérios. Fixação. Valor. Indenização. Acidente. Trânsito. Trata-se, na origem, de ação de reparação de danos materiais e morais em razão de acidente automobilístico que vitimou a esposa do recorrente. (...) é o arbitramento pelo juiz de forma equitativa, sempre observando o princípio da razoabilidade. No ordenamento pátrio, não há norma geral para o arbitramento de indenização por dano extrapatrimonial, mas háo art. 953, parágrafo único, do CC/2002, (...). Quanto à valorização de bem ou interesse jurídico lesado pelo evento danoso (vida, integridade física, liberdade, honra), constitui um critério bastante utilizado na prática judicial, consistindo em fixar as indenizações conforme os precedentes em casos semelhantes. Logo, o método mais adequado para um arbitramento razoável da indenização por dano extrapatrimonial resulta da união dos dois critérios analisados (valorização sucessiva tanto das circunstâncias como do interesse jurídico lesado). Assim, na primeira fase, arbitra-se o valor básico ou inicial da indenização, considerando o interesse jurídico lesado, em conformidade com os precedentes acerca da matéria e, na segunda fase, procede-se à fixação da indenização definitiva, ajustando-se o seu montante às peculiaridade do caso com base nas suas circunstâncias." REsp 959.780/ES, j. 26.04.2011, rel. Min. Paulo de Tarso Sanseverino. 
Sendo assim, para se verificar se há ou não dever de indenizar an debeatur, basta ação, nexo e dano. Já na verificação do quanto é devido quantum debeatur, a culpa é utilizada para reduzir a indenização. ${ }^{130}$

Já em um segundo momento conforme art. 945 do CC/2002 temos a aplicação da culpa concorrente no caso em que tanto o agressor como a vítima agiram culposamente, o juiz verificando os graus de culpa reduzirá o valor da indenização. ${ }^{131-132}$ A redução da indenização não será necessariamente em $50 \%$, pois se a vítima teve maior grau de culpa arcará com a maior parte de indenização. Porém, se a vítima teve culpa exclusiva o agressor nada paga, neste sentido:

"Processo civil e direito civil. Ação de indenização por danos materiais e compensação por danos morais e estéticos. Prequestionamento. Ausência. Acidente de trânsito. Negativa de prestação jurisdicional. Pretensão de reconhecimento de culpa concorrente da vítima. Condução de motocicleta sem habilitação e de chinelos. Análise da situação fática relativa ao acidente que exclui a concorrência de culpas. Dano material. Não limitação das cirurgias. Violação do art. 946 do CC/2002. Inocorrência. Fatos novos. Liquidação por artigos. Recuperação integral do dano. Compensação por danos morais e estéticos. Minoração. Impossibilidade. Incidência da Súmula 7 do STJ. Condenação. Dano moral. Montante inferior ao postulado. Sucumbência recíproca. Inexistência. Súmula 326 do STJ." STJ, REsp 604.758/RS, 3. ${ }^{a}$ T., j. 17.10.2006, rel. Min. Nancy Andrighi.

\section{Conclusão}

Conforme nítido se fez, o objeto do presente estudo relaciona com a responsabilidade civil automobilística, tendo em vista suma importância como fato social intrínseco da pós-modernidade.

Conforme levantamentos estatísticos elencados neste trabalho, se faz possível identificar que os acidentes automobilísticos constituem um problema mundial, tendo em vista as grandes perdas imateriais e materiais. Muitos são os fatores que contribuem para a incidência destes dados, porém os principais fatores são sociológicos e de fiscalização.

Em continuidade, referidos números e dados apresentados, decorrem de fatos sociais que envolvem diretamente a vida humana, cabendo à legislação,

130. Tartuce, Flávio. Op. cit., p. 364.

131. Diniz, Maria Helena. Op. cit., p. 300.

132. Peluso, Cezar et al. Op. cit., p. 790-791. 
à doutrina e aos tribunais, a tarefa de desenvolver e fixar parâmetros para solução destes conflitos.

Concluímos que a regulamentação específica para a presente matéria é Código de Trânsito Brasileiro - CTB, Lei 9.503/1997 fixa as normas que disciplinam os procedimentos de trânsito, tais como limites de velocidade, habilitação para dirigir etc., porém não regulamenta a questão atinente à responsabilidade civil.

Sendo assim, cabe a legislação civil, em especial nas suas cláusulas gerais previstas nos arts. 186 e 927 do CC/2002, estabelecerem os ditames da responsabilidade do acidente automotivo, ressalvadas as hipóteses especiais, não obstante a responsabilização nas esferas criminal e administrativa.

Ação de reparação de danos em acidente de veículo de via terrestre é processada pelo procedimento sumário nos termos do art. 275, II, d, do CPC, porém é possível sua conversão em procedimento ordinário com fundamento na celeridade processual, sendo possível dispensar a prova oral sem prejuízo às partes.

Concluímos ainda, que elementos ou pressupostos estão descritos no art. 186 do CC/2002, ou seja, ação ou omissão, nexo de causalidade, a culpa e por fim, o dano.

Referente ao causador do dano, responde por ação e por omissão, ou seja, via de regra, somente é responsável aquela pessoa que comete o ilícito, ficando excluído o de terceiro, salvo expressa previsão legal como o rol do art. 932 do CC/2002. Quanto à legitimidade ativa, pode propor a ação inicialmente a vítima do acidente automobilístico, bem como seus parentes no caso de morte daquele, sendo esta hipótese uma das poucas hipóteses de dano indireto consagrado no direito civil, em especial na questão dos alimentos conforme art. 948, II, do CC/2002.

Porém, pode ainda, somente o proprietário do veículo, propor a reparação do bem, porém o possuidor também é legitimado para a propositura a ação, como nos casos de leasing, compra e venda com reserva de domínio.

Já na legitimidade passiva, encontramos dois aspectos relevantes que devem ser observados, o primeiros deles é a dicotomia "condutor e proprietário", bem como em um segundo momento a responsabilidade civil por ato de terceiro previsto no art. 932 do CC/2002.

Em continuidade, o nexo de causalidade é o elemento imaterial da responsabilidade civil, ou seja, a relação de causa e efeito entre a conduta do agente (responsabilidade subjetiva), o risco da atividade (responsabilidade objetiva) e o dano sofrido pela vítima. Sendo assim, trata-se de um elemento indispen- 
sável para a caracterização do dever de indenizar, seja a responsabilidade subjetiva ou objetiva, porém, não sendo simples estabelecer no caso concreto sua relação de causa e efeito.

Em decorrência desta dificuldade, a doutrina se divide em três correntes quanto ao nexo de causalidade, quais sejam: (a) teoria do equivalente dos antecedentes ou conditio sine qua non (Von Buri); (b) teoria da causalidade adequada (Von Kries); e (c) teoria dos danos diretos e imediatos conforme segue.

Referente a estas teorias, concluímos que Flávio Tartuce, Aguiar Dias e Caio Mário adotam a da causalidade adequada, aventada no REsp 682.599/RS, porém para Orlando Gomes, Agostinho Alvim e Flavio Monteiro de Barros adotam a teoria dos danos diretos e imediatos, em razão da redação do art. 403 do CC/2002, bem como do REsp 1.113.804/RS.

Ainda quanto a este elemento, concluímos que o rompimento do nexo causal significa o desaparecimento do dever de indenizar, ou seja, é excludente de responsabilidade civil, já em havendo estado de necessidade ou legítima defesa, não há rompimento de nexo, mas em razão da licitude não há dever de indenizar.

Quanto à culpa, como regra geral, concluímos que esta decorre da inobservância de um dever de cuidado, bem como do dolo que é a culpa intencional que causa o dano, verificando assim a intenção do legislador nesta hipótese à preponderância da responsabilidade civil subjetiva.

O problema é que o ônus de provar a culpa será sempre da vítima do dano automobilístico, tal situação é tormentosa, pois muitas vezes existem apenas testemunhas presenciais, surgindo assim, versões antagônicas narradas pelas partes envolvidas, sendo necessário o julgamento improcedente, ainda que haja vítimas graves ou fatais.

Em razão das dificuldades, o direito percebe a insuficiência da teoria da responsabilidade subjetiva, a doutrina e a jurisprudência têm criando presunções de culpa, as quais possibilita o benefício da inversão do ônus da prova contra o causador do dano, bem como surgem as presunções de dano decorrentes da teoria do risco, ou seja, risco integral; a do risco administrativo; a do risco proveito; e a do risco criado.

Quanto ao dano, concluímos que este é essencial para surgir o dever de reparar, pois o dano é elemento essencial do ato ilícito.

Assim, neste sentido, verificamos que é uma lesão a um bem jurídico tutelado, que deve ser certo e atual. Porém, excepcionalmente, há determinadas situações em que não há necessidade de prova, pois este é presumido, como exemplo, a cláusula penal; o dano moral presumido - Súmula 388 do STJ, a 
simples apresentação do cheque "pré-datado" antes da data combinada (data do vencimento), gera dano moral presumido e via de regra o apontamento indevido no cadastro de maus pagadores gera dano moral presumido, contudo a Súmula 385 do STJ, entende que se houver um apontamento devido, não cabe indenização quanto ao apontamento indevido, mas garante o direito de cancelamento.

Quanto às espécies de dano, concluímos que algumas são suas espécies, dentre elas temos o dano individual, que decorre a verificação inerente a uma lesão a uma pessoa; o dano social que atinge direitos difusos ou coletivos, dentre eles o valor social do trabalho, o meio ambiente, a infância dentre outros.

Referente ao dano individual conforme aventado no presente trabalho, este pode compor as modalidades material, moral, estético, bem como de acordo com a hipótese de incidência podem ser cumulados em uma única ação, e o seu quantum indenizatório reduzido conforme impacto dos graus de culpa.

Diante de todo o exposto, podemos concluir que as cláusulas gerais previstas nos arts. 186 e 927 do CC/2002, estabelecerem os ditames da responsabilidade civil decorrente do acidente automotivo.

Referidas cláusulas devem ser preenchidas pelo magistrado de acordo com a casuística estabelecida quando do acidente, bem como tendo como critério, os elementos atinentes à responsabilidade civil, quais sejam: ação ou omissão, nexo de causalidade, a culpa e por fim, o dano.

\section{BIBLIOGRAFIA}

Bernardo, Wesley de Oliveira Louzada. Responsabilidade civil automobilística: por um sistema fundado na proteção à pessoa. São Paulo: Atlas, 2009.

Aguiar Dias, José de. Da responsabilidade civil. 10. ed. Rio de Janeiro: Forense, 1995. vol. II.

Dinız, Maria Helena. Curso de direito civil brasileiro. 16. ed. São Paulo: Saraiva, 2002. vol. 7 .

. Manual de direito civil. São Paulo: Saraiva, 2010.

Francioni, José Vieira. Trânsito - Acidente ou incidente? Disponível em: [www.transitodez.com.br/artigoacidenteouincidente.html]. Acesso em: 29.11.2011.

Gagliano, Pablo Stolze; Pamplona Filho, Rodolfo. Novo curso de direito civil: direito de família. São Paulo: Saraiva, 2011.

Gonçalves, Carlos Roberto. Comentários ao Código Civil. São Paulo: Saraiva, 2003. vol. 11. 

2011.

Hironaka, Giselda Maria Fernandes Novaes. Responsabilidade pressuposta. 6. ed. São Paulo: Del Rey, 2002.

IPEA. Relatório executivo - Impactos sociais e econômicos dos acidentes de trânsito nas aglomerações urbanas brasileiras. Disponível em: [www.ipea. gov.br/sites/000/2/estudospesq/Portugues.pdf]. Acesso em: 21.11.2011.

Lisboa, Roberto Senise. Manual de direito civil: obrigações e responsabilidade civil. 5. ed. São Paulo: Saraiva, 2010. vol. II.

Marques, Claudia Lima; Benjamin, Antonio Herman V.; Miragem, Bruno. Código de Defesa do Consumidor. 2. ed. São Paulo: Ed. RT, 2006.

Martins-Costa, Judith. Comentários ao novo Código Civil. Rio de Janeiro: Forense, 2003. vol. V, t. II.

Nery Junior, Nelson; Nery, Rosa Maria de Andrade. Código Civil anotado. 2. ed. São Paulo: Ed. RT, 2003.

Peluso, Cezar et al. Código Civil comentado: doutrina e jurisprudência. São Paulo: Manole, 2007.

R7. Acidente com moto vira problema de saúde pública em Pernambuco. Segundo Secretaria de Saúde, 52,1\% das vítimas envolvidas morrem em via pública. R7 Notícias. 11.01.2010. Disponível em: [http://noticias.r7.com/ saude/noticias/acidente-com-moto-vira-problemade-saude-publica-em-pernambuco-20100111.html]. Acesso em: 29.11.2011.

Rodrigues, Silvio. Direito civil: responsabilidade civil. 19. ed. São Paulo: Saraiva, 2002.

Stосо, Rui. Tratado de responsabilidade civil. 5. ed. São Paulo: Ed. RT, 2001.

TARTUCE, Flávio. Direito civil: obrigações e responsabilidade civil. 5. ed. São Paulo: Método, 2010.

Tepedino, Gustavo; Barbosa, Heloisa Helena; Moraes, Maria Celina Bodin de. Código Civil interpretado conforme a Constituição da República: parte geral e obrigações (arts. 1 a 420). 2. ed. Rio de Janeiro: Renovar, 2007. vol. I.

Theodoro Júnior, Humberto. Comentários ao novo Código Civil. Rio de Janeiro: Forense, 2003. vol. III, t. II.

UNESP. Acidente automobilístico. Disponível em: [www.bauru.unesp.br/curso_ cipa/artigos/4_transito.htm]. Acesso em: 29.11.2011.

Venosa, Silvio de Salvo. Direito civil: responsabilidade civil. 6. ed. São Paulo: Atlas, 2006. 


\section{Pesquisas do Editorial}

\section{Veja também Doutrina}

- Crimes de trânsito (primeiras reflexões sobre a Lei 9.503/97), de Fernando Yukio Fukassawa - RT 749/520;

- 0 direito à reparação dos danos morais e os acidentes de trânsito, de Geraldo Ferreira Lanfredi - RT 721/18;

- Relação de causalidade e o dever de indenizar, de Raimundo Gomes de Barros RDC 34/135; e

- Risco, solidariedade e responsabilidade objetiva, de Maria Celina Bodin de Moraes RT 854/11.

- A reparação nos acidentes de trânsito - Teoria geral da responsabilidade civil, de Arnaldo Rizzardo, 11. ed., São Paulo, Ed. RT, 2010.

\section{Veja também Jurisprudência}

- Aquaplanagem como causa de acidente de trânsito: RT 876/299; e

- Ciclista vs. ônibus: RT 911/723. 